\title{
Dietary, physiological, genetic and pathological influences on postprandial lipid metabolism
}

\author{
José Lopez-Miranda ${ }^{1}$, Christine Williams ${ }^{2}$ and Denis Lairon ${ }^{3 *}$ \\ ${ }^{1}$ Lipids and Atherosclerosis Research Unit, Department of Medicine. Hospital Universitario Reina Sofía, University of Cordoba, \\ Córdoba, Spain \\ ${ }^{2}$ Hugh Sinclair Unit of Human Nutrition, School of Food Biosciences, University of Reading, 226 Whiteknights, Reading, \\ Berkshire, RG6 6AP, UK \\ ${ }^{3}$ INSERM, 476 Nutrition Humaine et lipides, Marseille, F-13385 France; INRA, 1260, Marseille, F-13385 France; Université \\ Méditerranée Aix-Marseille 2, Faculté de Médecine, IPHM-IFR 125, Marseille, F-13385 France
}

(Received 8 November 2006 - Revised 21 February 2007 - Accepted 12 March 2007)

\begin{abstract}
Most of diurnal time is spent in a postprandial state due to successive meal intakes during the day. As long as the meals contain enough fat, a transient increase in triacylglycerolaemia and a change in lipoprotein pattern occurs. The extent and kinetics of such postprandial changes are highly variable and are modulated by numerous factors. This review focuses on factors affecting postprandial lipoprotein metabolism and genes, their variability and their relationship with intermediate phenotypes and risk of CHD. Postprandial lipoprotein metabolism is modulated by background dietary pattern as well as meal composition (fat amount and type, carbohydrate, protein, fibre, alcohol) and several lifestyle conditions (physical activity, tobacco use), physiological factors (age, gender, menopausal status) and pathological conditions (obesity, insulin resistance, diabetes mellitus). The roles of many genes have been explored in order to establish the possible implications of their variability in lipid metabolism and CHD risk. The postprandial lipid response has been shown to be modified by polymorphisms within the genes for apo A-I, A-IV, A-V, E, B, C-I and C-III, lipoprotein lipase, hepatic lipase, fatty acid binding and transport proteins, microsomal triglyceride transfer protein and scavenger receptor class B type I. Overall, the variability in postprandial response is important and complex, and the interactions between nutrients or dietary or meal compositions and gene variants need further investigation. The extent of present knowledge and needs for future studies are discussed in light of ongoing developments in nutrigenetics.
\end{abstract}

Postprandial lipaemia: Coronary heart disease: Gene polymorphism: Diet: Lifestyle conditions: Physiological and pathological factors

\section{Definition and importance of postprandial lipaemia}

Much of our knowledge about the relationship between lipid, lipoprotein metabolism and the development of atherosclerosis and CVD is based on measurements in the fasting state essentially reflecting endogenous metabolism (Fig. 1). Although such measurements remain the foundation of clinical assessment and an important basis for decisions regarding hypolipidaemic interventions, it should be acknowledged that we spend a considerable amount of time in a non-fasting, postprandial state. Based on typical Western eating patterns, most people consume three or more meals a day, each containing 20-70 g fat ${ }^{1}$. Except at breakfast, each of these meals is most likely consumed before plasma triacylglycerol (TAG) levels have returned to baseline from the lipaemic conditions resulting from the previous intake. Thus, people spend the majority of their daytime in a postprandial (fed) state, with a continual fluctuation in the degree of lipaemia throughout the day.

The postprandial state is a dynamic, non-steady-state condition, with rapid remodelling of lipoproteins compared with the relatively stable fasting condition (Fig. 1). Determination of the postprandial response is complex, and it is therefore more challenging to assess the cardiovascular risk associated with postprandial lipaemia than that during fasting conditions. In spite of this, it is becoming increasingly evident that future efforts to study and treat lipids related to atherogenesis should include postprandial parameters. The aim of this paper is to consider the regulatory pathways of postprandial lipoproteins and the major factors, including nutrition, lifestyle, physiopathology and genetics, that may contribute to interindividual variability in postprandial lipaemia, and thereby susceptibility to atherosclerosis.

\section{Experimental evidence linking postprandial lipaemia with} atherosclerosis

The potential atherogenicity of postprandial TAG and TAGrich lipoprotein (TRL) levels did not gain widespread attention until the idea was put forward in a widely quoted paper by Zilversmit in $1979^{2}$, who proposed that

\footnotetext{
Abbreviations: LPL, lipoprotein lipase; TRL, triacylglycerol-rich lipoprotein.

* Corresponding author: Dr Denis Lairon, fax +33 4917821 01, email denis.lairon@medecine.univ-mrs.fr.
} 
Lipoprotein metabolism

Exogenous -Pathway -Endogenous

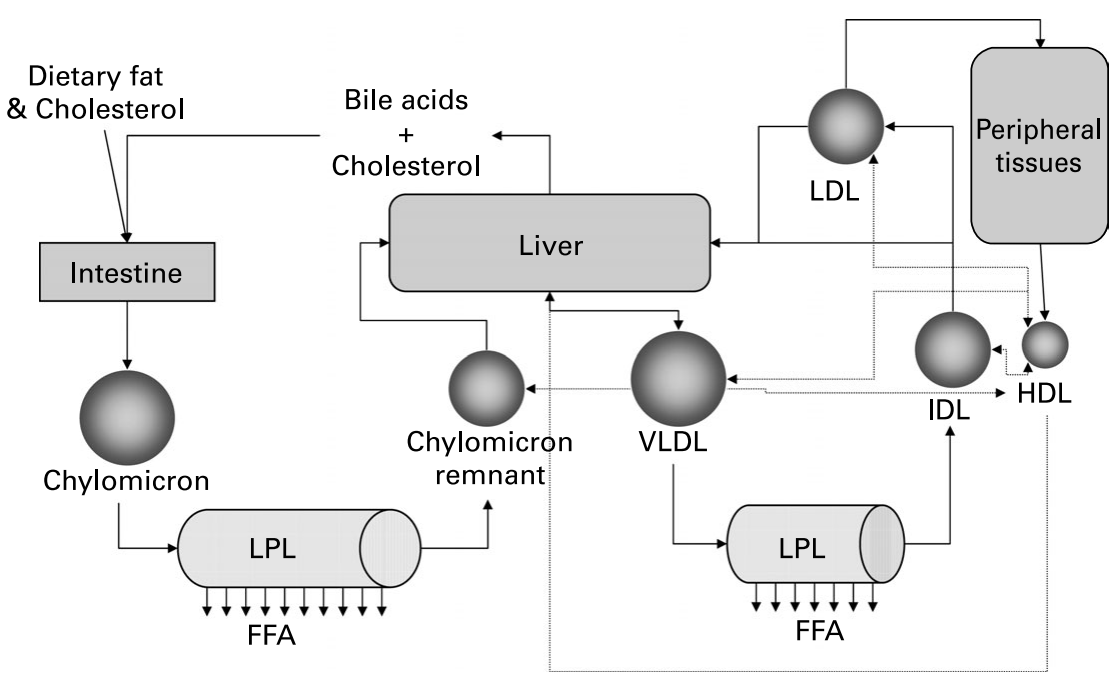

Fig. 1. Human lipoprotein metabolism. Dietary free fatty acids (FFA) are absorbed from the gut and converted to triacylglycerols to be incorporated into chylomicrons in the intestinal epithelial cells. The triglyceride-rich apo B-48-containing chylomicrons enter the plasma via the intestinal lymph. Lipoprotein lipase (LPL) hydrolyses the triacylglycerol in chylomicrons to fatty acids, which are taken up by muscle cells for oxidation or adipocytes for storage. The remaining particles, the chylomicron remnants, are removed from the circulation by the liver through binding of their surface apo $E$ to the LDL receptor or LDL receptor-related protein. VLDL particles are triacylglycerol-rich apo B-100-containing particles, synthesised by the liver. As with chylomicrons, VLDL triacylglycerols are hydrolysed by LPL. VLDL remnants or IDL are taken up by liver receptors via apo $\mathrm{E}$ or converted to LDL. Chylomicrons, VLDL and their respective remnants (remnant lipoproteins) are termed triacylglycerol-rich lipoproteins (TRL). Under physiological conditions, insulin, which is raised in the postprandial state, suppresses lipolysis from adipose tissue and hepatic VLDL production, but this insulin action is inappropriate in insulin resistance and type 2 diabetes, resulting in high TRL concentrations. The large amount of TRL and their prolonged residence time in the circulation increase the exchange of esterified cholesterol from HDL and LDL to TRL, and of triacylglycerols to LDL and HDL particles, which is mediated by cholesterol-ester transfer protein. Triacylglycerol enrichment of LDL particles renders them better substrates for hepatic lipase, which hydrolyses triacylglycerols from the core of LDL and turns them into smaller and denser particles. Small, dense LDL are more atherogenic as they readily enter the subendothelial space and become oxidised. Triacylglycerol-enriched HDL particles are smaller and are more rapidly catabolised, which may explain the observed low plasma HDL in insulin resistance and type 2 diabetes.

the hydrolysis of chylomicron by lipoprotein lipase (LPL) resulted in the subsequent internalisation of cholesterol ester-enriched chylomicron remnants by arterial smooth muscle cells. A confirmation of this hypothesis has been complicated by the multiple factors affecting the postprandial response, the lack of standardised methodology and the considerable heterogeneity between postprandial TRL species. Evidence supporting an association between postprandial lipaemia and atherosclerosis has been provided by clinical trials and mechanistic studies of both the direct and indirect effects of TRL using animal models and cell culture.

\section{Clinical trials}

Several clinical studies have shown that a delayed elimination of postprandial TRL is associated with atherosclerosis (Tables 1 and 2). There are also reports of an association between postprandial lipaemic response and subsequent progression of atherosclerosis in patients with pre-existing CHD.

In men, the presence of CHD is associated with higher postprandial TAG concentrations in plasma compared with healthy controls, even after correction for higher levels of fasting TAG in the CHD group $^{3-6}$. The data are less clear for women. One smaller study reported elevated postprandial TAG and apo B-48 concentrations in women with $\mathrm{CHD}^{6}$. However, a larger study showed no significant relationship between prolonged postprandial lipaemia and $\mathrm{CHD}$ in middle-aged women ${ }^{7}$. In a number of studies, carotid intima-media thickness is used as a surrogate marker for atherosclerosis $^{8-10}$. Several studies have confirmed a positive association between carotid intima-media thickness and postprandial lipaemia ${ }^{8-11}$. However, these data do not address the issue of whether prolonged postprandial lipaemia predicts risk of developing CHD or whether the presence of CHD results in a subsequent impairment of postprandial TRL.

In order to address this question, one cross-sectional study examined postprandial TAG levels after the consumption of a high-fat liquid drink in the healthy sons of men with angiographic evidence of severe CHD compared with the sons of control subjects without $\mathrm{CHD}^{12}$. In spite of comparable fasting lipids between groups, the sons of men with CHD had significantly higher plasma TAG levels after 8,10 and $12 \mathrm{~h}$ postprandially, indicative of a delayed clearance of TAG. In another study in the offspring of patients with CHD, young men with (case subjects) or without (control subjects) a paternal history of CHD underwent a postprandial study. Although no difference in postprandial TAG was found in the groups as whole, subgroup analysis revealed an increased postprandial response among individuals with a moderate elevation of fasting TAG level ${ }^{13}$. There is evidence that higher levels of TRL or their remnants predict the progression of disease in subjects with established CHD. In The Montreal Heart 
Table 1. Clinical trials summarizing the effect of postprandial lipoprotein metabolism on coronary artery disease (CAD)

\begin{tabular}{l} 
Study population/design \\
\hline Sixty-one male subjects with severe CAD and 40 control subjects \\
without CAD as verified by angiography (Case-control) ${ }^{4}$ \\
Two group of 20 normolipidaemic men, a group of CAD patients \\
and a matched control group with documented minimal coronary \\
atherosclerosis (Case-control) \\
Twelve normocholesterolaemic, normotriacylglycolaemic women with \\
angiographically proven CAD, and 12 individually matched controls, \\
without angiographical abnormalities (Case-control)
\end{tabular}

Ninety-two men and 113 women were recruited from populations undergoing diagnostic exercise electrocardiographic or thallium stress tests. Twenty-six men and 24 women had positive tests. Case-Control $^{7}$

Male subjects with a paternal history of CHD (cases, $n=407$ ) and age-matched male controls $(n=415)$ were recruited from 14 European universities. Case-control ${ }^{13}$

Eighty sons of men with severe coronary artery disease and 55 sons of controls (Case-control) ${ }^{12}$
Main results

Single postprandial triglyceride levels 6 and $8 \mathrm{~h}$ after the meal were highly discriminatory $(P<0.001)$ and by logistic-regression analysis displayed an accuracy of $68 \%$ in predicting the presence or absence of CAD

Patients with CAD showed a marked delay in the clearance of retinyl esters as well as in the normalisation of plasma triacylglycerol concentrations. Post-heparin plasma hepatic lipase activity was significantly lower in the CAD group

A greater absolute and incremental apo B-48 response in the IDL fraction $(d=1.006-1.019 \mathrm{~g} / \mathrm{ml})$ was observed in cases with CAD (incremental area under the curve 0.40 (SD 0.12) than controls $(0.01$ (SD 0.06) $P=0.01$ ). The results provide evidence that the metabolism of intestinal triglyceride-rich lipoproteins is significantly different in normolipidaemic women with angiographically proven CAD compared with individually matched controls without coronary disease

They chose exercise-induced myocardial ischemia (EIMI) as the criterion for defining case and control subjects because they wanted participants who did not have a prior diagnosis of CAD. Among men but not women postprandial TG and RP responses were associated with EIMI independent of age, race, and smoking status. In the male group, the odds ratio $(\mathrm{OR})$ for an increase in postprandial TG response of approximately $1 \mathrm{SD}$ was $1.69(P=0.007)$; the OR for an increase in $\mathrm{RP}$ response of $1 \mathrm{SD}$ was $2.47(P=0.011)$

In the sample as a whole, the postprandial triglyceride responses did not significantly differ between the two groups. However, in the upper tertile of fasting triglycerides, cases displayed a higher area under the curve (5.71 vs. $4.49 \mathrm{mmol} . \mathrm{h} \mathrm{L-1}, P<0.001)$, a higher peak (1.76 vs. $1.43 \mathrm{mmol} \mathrm{L}-1, P<0.001)$ and a more delayed time to peak (3.15 vs. $2.91 \mathrm{~h}, P<0.05)$ than controls.

Healthy young adult sons, whose fathers had established CAD, showed prolonged postprandial hypertriacylglycerolaemia (difference $0.35 \mathrm{mmol} / \mathrm{l}, 95 \% \mathrm{Cl} 0.07,0.62 \mathrm{mmol} / \mathrm{l})$ at $8 \mathrm{~h}$
Study, undertaken in 335 men and women with moderate-toextensive CHD, the concentration of hepatic TRL remnants predicted the progression of atherosclerosis ${ }^{14}$. In a summary of clinical studies of postprandial lipaemia and atherosclerosis, Karpe $^{15}$ suggested that an elevated plasma TAG measured at late postprandial time points after fat intake might reveal a state of fat intolerance linked to an elevated risk of CHD that was under genetic control and could not be detected by a simple measurement of fasting plasma TAG. However, additional studies are needed to determine the effect of specific TRL fractions and the underlying mechanisms for a link between postprandial lipaemia and atherosclerosis.

Table 2. Clinical trials summarising the effect of postprandial lipoprotein metabolism on carotid artery atherosclerosis

\begin{tabular}{|c|c|}
\hline Study population & Main results \\
\hline $\begin{array}{l}\text { Ninety-six healthy } 50 \text {-year-old men with an apo E-3/E-3 genotype } \\
\text { underwent an oral fat tolerance test and B-mode carotid } \\
\text { ultrasound examination }{ }^{10}\end{array}$ & $\begin{array}{l}\text { In the postprandial state, plasma triacylglycerols at } 1-4 \mathrm{~h} \text {, total } \\
\text { triacylglycerol area under the curve (AUC), incremental triacylglycerol } \\
\text { AUC and the large VLDL (Sf } 60-400 \text { apo B-100) concentration at } 3 \mathrm{~h} \\
\text { were significantly related to carotid artery IMT. Multivariate analyses } \\
\text { showed that plasma triacylglycerols at } 2 \mathrm{~h} \text {, LDL-cholesterol and basal } \\
\text { proinsulin levels were consistently and independently related to IMT }\end{array}$ \\
\hline $\begin{array}{l}\text { IMT and postprandial triacylglycerol-rich lipoprotein was quantified } \\
\text { during a standardised oral fat tolerance test in } 30 \text { healthy } \\
\text { normo- and hypertriacylglycerolaemic middle-aged men }\end{array}$ & $\begin{array}{l}\text { Postprandial plasma triacylglycerols, in particular those measured late } \\
(6 \mathrm{~h}) \text { after intake of the test meal, correlated positively with the IMT } \\
(r=0.44, P<0.05) . \text { In a multivariate analysis, } 39 \% \text { of the total } \\
\text { variability for the common carotid IMT was explained by age, } \\
\text { LDL-cholesterol and the postprandial triacylglycerol level }\end{array}$ \\
\hline $\begin{array}{l}\text { Forty-seven middle-aged, moderately hypercholesterolaemic } \\
\text { individuals were recruited }\end{array}$ & $\begin{array}{l}\text { The only variable that showed a univariate correlation with B-mode } \\
\text { score was peak triacylglycerol response. Forward-selection stepwise } \\
\text { regression resulted in the inclusion of only peak triacylglycerol } \\
\text { response and smoking history as important predictors of carotid wall } \\
\text { thickness in a linear model }\end{array}$ \\
\hline $\begin{array}{l}\text { Seventy-two healthy men with an apo E-3/E-3 genotype who had } \\
\text { undergone an oral fat load test and } \mathrm{B} \text {-mode ultrasound } \\
\text { examination of } \mathrm{IMT}^{11}\end{array}$ & $\begin{array}{l}\text { Multivariate analysis revealed that the apo C-I content of } \\
\text { triacylglycerol-rich lipoprotein at } 6 \mathrm{~h} \text {, plasma triacylglycerol } \\
\text { concentrations at } 2 \mathrm{~h} \text { and fasting plasma cholesterol } \\
\text { concentration independently predicted IMT }\end{array}$ \\
\hline
\end{tabular}

IMT, intima-media thickness. 


\section{Mechanistic evidence}

The pathogenesis of the relationship between postprandial TRL and CHD remains unclear, but experimental evidence has provided several plausible mechanisms. Atherogenic effects may be mediated directly by TRL particles or components of the particles. A variety of in vitro and clinical studies suggest that postprandial chylomicrons and VLDL are associated with adverse effects on the arterial endothelium (Fig. 2). In cell culture studies, TRL, particularly postprandial remnants, is directly cytotoxic to endothelial cells ${ }^{16}$. Clinical evidence also demonstrates that postprandial TRL adversely affects the endothelium by mediating changes in vascular tone. After the consumption of a high-fat meal, a reduction in flow-induced dilation of the brachial artery correlated with postprandial plasma TAG concentration in healthy subjects ${ }^{17}$. Incubation with remnant lipoproteins, but not VLDL or LDL, induced an elevation in the expression of intercellular adhesion molecule-1, vascular cell adhesion molecule-1 and tissue factor in a human umbilical vein endothelial cell model, in part through a redox-sensitive mechanism ${ }^{18}$. In addition, indirect mechanisms of TRL atherogenicity may be related to metabolic changes associated with the presence of postprandial TRL. Of particular interest is TRL-mediated modification in LDL composition and size with the generation of small, dense $\mathrm{LDL}^{19}$.

The composition and cholesterol concentration of HDL is inversely related to the magnitude of postprandial lipaemia and the plasma concentration of TAG. Postprandial lipaemia has been shown to be associated with changes in haemostatic variables known to promote the risk of thrombotic events ${ }^{20}$. Following the intake of a fat-rich meal, factor VIIc is transiently increased due to an increase in plasma concentration of factor $\mathrm{VIIa}^{20}$. A postprandial decline in plasminogen activator inhibitor type-1 activity and an increase in tissue plasminogen activator activity have been observed in various studies $^{21,22}$. Finally, postprandial lipaemia is associated with a mild increase in platelet reactivity that increases the expression of cell-surface markers in healthy men ${ }^{23,24}$.

\section{Factors affecting the postprandial response}

\section{Meal size and composition}

Postprandial lipaemia is influenced by the amount and type of dietary fat present in the test meal, as well as other dietary components, including fibre, glucose, starch and alcohol ${ }^{25-27}$. The amount and type of dietary fat modulate postprandial lipaemia. The intake of long-chain omega (n)-3 PUFA (predominantly fish oil), results in lower TAG levels and attenuates postprandial lipaemia ${ }^{28}$.

Fat. The amount of fat required to result in significant elevations in plasma TAG concentration is in the order of $30-50 \mathrm{~g}$. Some studies have been performed with increasing doses of dietary fat ${ }^{29-32}$. In these studies, a very low $(5 \mathrm{~g})$ or low (15 g) dose of dietary fat does not significantly increase triacylglycerolaemia postprandially; moderate doses (30-50 g) dose-dependently increase postprandial triacylglycerolaemia (from 0.9 to $1.3 \mathrm{mmol} / \mathrm{l}$ above baseline, respectively); and finally, very high doses ( $80 \mathrm{~g}$ and above) exaggerate postprandial triacylglycerolaemia but without dose-dependence. On the other hand, consecutive meals containing fat appear to enhance the lipaemia ${ }^{33}$. Most meals contain 20-40 g fat, so that when two or three such meals are eaten consecutively, along with snacks eaten between meals, this pattern of consumption might be expected to maintain circulating TAG well above fasting concentrations for much of the day. Studies that have monitored TAG responses overnight following a fat-containing evening meal have shown values to be elevated for $7-8 \mathrm{~h}$ after the meal, only falling towards fasting values between 04.00 and 06.00 hours ${ }^{34}$.

Studies have also addressed fatty acid composition. A relatively large number of acute meal studies have attempted to compare the effects on postprandial lipaemia of meals of

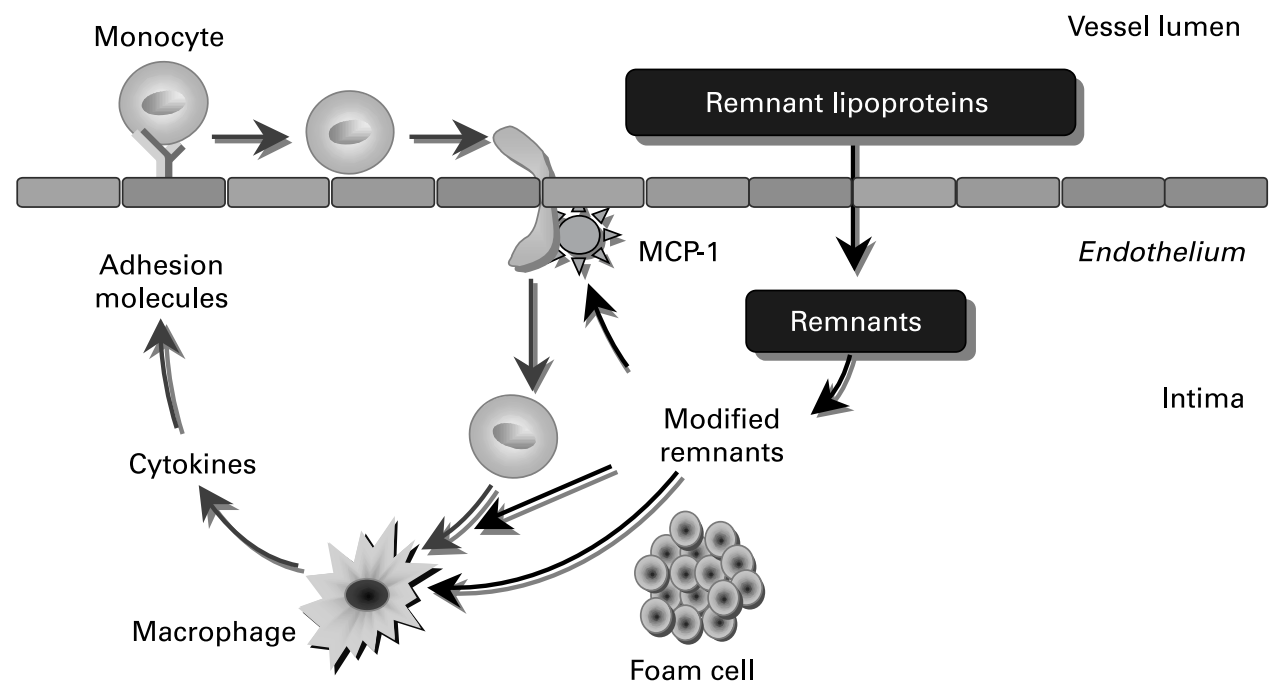

Fig. 2. The effects of postprandial chylomicrons and VLDL on arterial endothelium. VLDL remnants and chylomicron remnants behave in much the same way as LDL. They enter the subendothelial space, where they become modified, and the modified remnants stimulate Chemoattractant protein-1 (MCP-1), promote the differentiation of monocytes into macrophages and are taken up by the macrophages to form foam cells. Like LDL, the remnant lipoproteins are proinflammatory and proatherogenic. 
different fat type (reviewed by Williams, 1998) 27,35-37. A number of potentially confounding factors, such as amount of fat, type and amount of carbohydrate and physicochemical composition of the meal ${ }^{38,39}$, have differed between many of the studies, which makes comparison difficult, and clear conclusions cannot always be drawn. In this respect, it should be remembered that short or medium dietary fatty acids have a limited effect on postprandial plasma TAG response because they enter the portal route instead of chylomicron secretion into the general circulation. Dairy fats contain significant amounts of short- and medium-chain fatty acids so that studies that have used dairy fats as the source of saturated fatty acids (SFA) generally report, as expected, a lower postprandial TAG response than with other SFA or other types of fat. Taking account of these considerations, most studies have shown that meals enriched with SFA, MUFA or n-6 PUFA do not generally elicit markedly different postprandial lipid responses. However, some studies report exacerbated ${ }^{36}$ or reduced $^{37}$ responses after an intake of saturated butter fat.

Comparisons of the effect of $n$-6 PUFA-rich oils with olive oil (rich in oleic acid) or MUFA (rapeseed oil) have shown a lower ${ }^{40}$ or comparable magnitude of postprandial lipaemia ${ }^{37,41,42}$. Eating $n-3$ PUFA (fish oil) can lower the postprandial TAG response if a sufficient amount is present within the test meal ${ }^{43}$, but the levels used were far greater than those which would be consumed by most populations. Furthermore, several studies have shown that differences in single-meal fatty acid composition exert little or no effect on postprandial changes in plasma lipids ${ }^{40,44-46}$. The influence of the positional distribution of fatty acids within the dietary TAG moieties has been investigated, some showing some influence ${ }^{47}$ but others no effect ${ }^{43}$ on postprandial lipaemia.

Several studies have found striking findings with regard to the effect of stearic acid-rich fats compared with other SFA on postprandial lipaemia. Two independent studies have found that a stearic acid-rich TAG prepared from a randomised blend of hydrogenated and unhydrogenated high-oleic sunflower oil resulted in decreased postprandial lipaemia compared with unhydrogenated high-oleic acid sunflower oil ${ }^{22,48}$. However, a stearic acid-rich meal using cocoa butter resulted in similar postprandial lipaemia compared with a meal rich in oleate provided by high-oleic sunflower ${ }^{21}$. Yet in the same study, a synthetic randomised stearic-rich TAG was found to decrease postprandial lipaemia. It was hypothesised that the unique symmetrical TAG structure of cocoa butter, in which almost all of the stearic acid is present as 1,3 di-stearyl, 2 mono-oleylglycerol, was responsible for this difference. In order to test this hypothesis, the postprandial effects of randomised cocoa butter were compared with unrandomised cocoa butter ${ }^{49}$. It currently remains uncertain whether these effects are solely due to TAG structure or are related to changes in the physicochemical properties of the TAG mixture.

Measurement of the postprandial TAG response may provide only a limited evaluation of the true impact of meal fat type on postprandial lipoprotein metabolism.

More recently, studies that have measured particle number (evaluated by apo B-48 response), and which have measured responses in different lipoprotein subfractions, have revealed important differences in lipid, apo, particle size and number in response to meals of different fatty acid composition. The studies showed lipaemic responses to be in the order SFA $>$ MUFA $>$ PUFA. This suggests that findings from studies that have employed plasma TAG analysis alone may have underestimated the impact of meal fatty acid composition on postprandial lipoprotein metabolism ${ }^{33,50,51}$. Meals containing olive oil, with oleic acid, result in a greater apo B-48 response compared with palm oil, safflower oil, and a mixture of fish and safflower oil, and it stimulated the formation of both small (S[f] 60-400) and large (S[f] > 400) apo B-48-containing lipoproteins ${ }^{50}$. This finding is consistent with data from Caco- 2 cell culture studies ${ }^{52}$, which demonstrated that oleic acid is a potent stimulator of TAG secretion, and consistent with other test-meal studies reporting that meals high in oleic acid-rich oils (e.g. high-oleic sunflower oil) result in a more pronounced and sharper postprandial rise in plasma TAG than -s seen with SFA-rich meals ${ }^{48}$, although the overall TAG response measured as area under the curve does not differ from other fat type meals.

Because it is unclear exactly how postprandial lipaemia impacts on atherosclerosis and CHD risk, the relevance of reported differences in the pattern and timing of the TAG response, as well as in particle number and particle size, elicited by meal fat type, is not yet fully understood. However, it is generally agreed that an elevated TAG response that continues into the late postprandial phase $(5-8 \mathrm{~h})$ is unfavourable $^{4}$; such a response is most commonly observed when non-dairy SFA meals are fed ${ }^{48,53}$.

The habitual diet of an individual may also influence the postprandial response ${ }^{27}$, but far fewer data have been published on this aspect ${ }^{34,35,53-55}$. Background tested diets rich in MUFA or $n-6$ PUFA tend to lower the postprandial lipid response compared with $\mathrm{SFA}^{43,54,55}$. Compared with an SFA-rich diet, an increase in chronic MUFA intake led to a marked reduction (by 21-54\%) in apo B-48 production following the test meal, but postprandial lipaemia did not differ, which indicated that MUFA diets results in the production of chylomicrons of a larger size ${ }^{56}$, suggested to be an advantage in the postprandial processing of dietary TAG. However, Rivellese et al. could find no difference in postprandial lipaemia on administration of a diet high in MUFA compared with diets high in $\mathrm{SFA}^{57}$. On the other hand, postprandial lipaemia has been shown to be greater on higholeic acid and trans-18:1 diets compared with a high-carbohydrate $\operatorname{diet}^{58}$. Comparisons of the effect of $n-6$ PUFA-rich oils with olive oil (rich in n-9 MUFA) or MUFA showed lower or comparable magnitude of postprandial lipae$\operatorname{mia}^{37,41,42}$.

It is well documented that diets rich in long-chain $n$-3 PUFA can lower the postprandial TAG response as long as a high intake $(2 \cdot 7-4 \mathrm{~g} / \mathrm{d})$ are given ${ }^{34}$, but some opposite effects have also been found ${ }^{59}$. In several studies, LPL activity is increased by supplementation with $3-4 \mathrm{~g} / \mathrm{d}$ long-chain $n-3$ PUFA $^{57,60,61}$. In contrast, the consumption of a diet rich in $\alpha$-linolenic acid (18:3n-3) containing an intake of between 4.5 and $9.5 \mathrm{~g} / \mathrm{d}$ taken as margarine for 6 months had no effect on postprandial lipaemia ${ }^{62}$. There is abundant evidence indicating that the reduction in postprandial lipaemia following $n$-3 PUFA supplementation is due to a decrease in chylomicron $^{63,64}$ and VLDL-TAG ${ }^{64-66}$ synthesis/secretion. On the other hand, there is also limited evidence supporting the hypothesis that the reduction in postprandial lipaemia 
following $n$-3 PUFA supplementation is due to an increased rate of TAG clearance associated with increased endogenous (measured in non-heparinised plasma) LPL activity ${ }^{61,67}$. A logical conclusion from the above studies would be that both a decrease in chylomicron and VLDL-TAG secretion/ synthesis, along with an increased clearance rate, was responsible for the postprandial reductions in lipaemia following $n-3$ PUFA supplementation.

Overall, studies that have evaluated impact of habitual fat type on postprandial response to acute fat ingestion have shown that, in terms of postprandial TAG response, effects are in the order SFA $>$ MUFA $=n-6$ PUFA $>n-3$ PUFA.

Carbohydrate. Clinical studies support the concept that diets rich in highly digestible carbohydrate can lead to elevation in fasting plasma TAG as a result of hepatic VLDL and chylomicron remnants accumulation due to altered lipoprotein secretion and/or clearance, as reviewed ${ }^{68,69}$. Also, several studies have shown that the amount or nature of carbohydrate in a meal alter postprandial lipid metabolism. Data obtained after the addition of glucose $(50 \mathrm{~g}, 100 \mathrm{~g})$ to fatty test meals have not shown consistent findings in healthy subjects $^{25}$, whereas the addition of sucrose or fructose has consistently been shown to increase postprandial triacylglycerolaemia $^{70}$. In healthy subjects, physiological ranges of postprandial hyperglycaemia and hyperinsulinaemia as generated by starchy foods (white bread, pasta, beans) do not induce noticeable alterations in the overall postprandial TAG response $^{71}$. Furthermore, the data obtained in this study showed that portal and peripheral hyperinsulinism (modulated using different test meals) delays and exacerbates the postprandial accumulation of intestinally derived chylomicrons in plasma ${ }^{71}$. Moreover, in subjects with insulin resistance, the ingestion of a high-glycaemic index mixed meal, compared with a low-glycaemic index one, increases the postprandial rise in insulinaemia and the accumulation of apo B-100- and apo B-48-containing TRL in those subjects, thus increasing postprandial triacylglycerolaemia as well as modifying the kinetics of peak occurrence ${ }^{72}$. Adding various digestible carbohydrates to a test meal can elicit a biphasic response of postprandial lipaemia ${ }^{72}$. This indicates clearly that the amount as well as the nature of carbohydrate can influence postprandial lipid responses.

Fibre. The addition of some dietary fibre sources into mixed test meals ${ }^{73,74}$ at the level of $4-10 \mathrm{~g} /$ meal can moderately reduce postprandial triacylglycerolaemia (by 17-24\%) or chylomicron lipids as generated by a mixed meal. Sources of soluble viscous fibre (e.g. oat bran) or with hypotriacylglycerolaemic properties (e.g. wheat germ) were shown to display a delay in the micellar lipid solubilisation process and a consequent reduction (by $37 \%$ ) in the secretion of chylomicrons into the circulation ${ }^{74}$. These data suggest that soluble fibre reduces the rate of digestion of dietary fats and thereby attenuates the postprandial lipaemic response.

Protein. Very little information is available so far regarding the influence of the amount or nature of dietary proteins on postprandial lipid responses. There is, however, evidence indicating that a diet of $20 \mathrm{~g}$ soy protein isolate for 3 weeks reduces baseline plasma remnant-like particle-cholesterol levels by $9.8 \%^{75}$. Recent studies have shown that postprandial lipaemia can be acutely mitigated when proteins are added to the fatty meal ${ }^{76}$. By contrast, a low-protein diet exacerbates the postprandial chylomicron concentration in moderately dyslipidaemic subjects in comparison to a lean red meat proteinenriched diet ${ }^{77}$. Casein added to a fatty meal markedly lowers NEFA in the postprandial and postabsorption phases, and also moderately reduces (by $20 \%$ ) postprandial lipaemia ${ }^{64}$.

\section{Lifestyle conditions}

Physical activity. An acute bout of aerobic exercise has been shown to significantly reduce postprandial lipaemia by $24-35 \%{ }^{78-82}$ and to significantly increase LPL activity ${ }^{83-85}$. The mitigation of the lipaemic response to a meal high in fat and carbohydrate is related to the intensity and/or energy expenditure of the preceding exercise ${ }^{80}$. Physical activity within the $24 \mathrm{~h}$ preceding a high-fat meal greatly improves the rate at which lipids are removed from the circulation. In a meta-analysis of data from interventions involving exercise, it was estimated that there was a reduction of $0.5 \mathrm{SD}$ in the postprandial TAG response in groups that had taken exercise before ingesting a meal ${ }^{86}$. Furthermore, the postprandial response to an oral fat load is lower, and the clearance rates of TRL are higher, in endurance-trained individuals compared with untrained control subjects, although this may not be applicable to moderate exercise ${ }^{87}$. In a recent article, the combination of exercise and $n-3$ PUFA supplementation reduced postprandial lipaemia response, measured as the incremental area under the postprandial curve of TAG, to a greater degree in recreationally active males when compared with the two treatments individually ${ }^{88}$.

Smoking. Axelson et al. ${ }^{89}$ showed a $50 \%$ greater TAG postprandial increase in habitual smokers without changes in fasting TAG. Mero et al. ${ }^{90}$ showed that smoking raised retinyl esters and apo B-48 (by 170\%), but not apo B-100. Data obtained in a large sample of men and women support the interpretation of Axelson et al. that smoking affects postprandial TAG metabolism primarily by raising lipoproteins of intestinal origin because cigarette smokers had substantially greater postprandial retinyl palmitate and apo B-48 (by 114-259\%) responses than did non-smokers, when adjusted for fasting triacylglycerols ${ }^{91}$.

Alcohol. The effect of alcohol on postprandial lipids has drawn continued attention over the past 10 years. Clearly, ethanol consumed with a meal elevates total plasma and VLDL-TAG. In a recent study ${ }^{92}$, the addition of $47.5 \mathrm{~g}$ alcohol to a high-fat meal (54\% of energy) was associated with an approximately $60 \%$ increase in the peak plasma TAG concentration compared with a meal consumed without alcohol. The authors attributed this increase to a stimulation of large VLDL secretion. Ethanol has also been shown to increase fatty acid synthesis $^{93}$ and also to reduce TAG clearance from the plasma $^{94}$.

\section{Physiological factors}

Age. In general, tolerance to oral fat intake decreases with age $^{1}$. Information on postprandial lipaemia in children is sparse, but, interestingly, there has been shown to be a significant difference in postprandial response between children and their mothers in spite of similar baseline TAG levels ${ }^{95}$. There also appears to be an age-related change in postprandial 
lipaemia and LPL activity ${ }^{96}$, which may in part be attributable to weight gain.

Gender and menopausal status. A number of studies have demonstrated significant differences between fasting and postprandial TAG levels in men and women, with higher levels in men ${ }^{1}$. It is noteworthy that, for a given meal, the postprandial lipid response is lower in women than men, due to a higher clearance capacity caused by an increase in LPL activity.

Additional evidence for the presence of exaggerated postprandial lipaemia in postmenopausal women has been reported after adjusting by fasting $\mathrm{TAG}^{97}$. There are several possible mechanisms that might promote the uptake of fat in women. Oestradiol probably promotes a rapid clearance of chylomicron remnants through its effects on the LDL receptor, but it may also promote more effective fatty acid trapping by subcutaneous adipose stores. It is noteworthy that, for a given meal, the postprandial lipid response is lower in women than men, due to a higher clearance capacity caused by an increase in LPL activity. On the other hand, hormone replacement therapy is associated with an increase in TAG in parallel with a decrease in remnant lipoprotein-cholesterol levels ${ }^{98}$. These results suggest that oestrogen might induce a shift in the distribution pattern of TRL, with a decrease of the more atherogenic fractions.

\section{Pathological conditions}

Obesity. Obesity, especially central adiposity, is frequently associated with several metabolic abnormalities, including hypertriacylglycerolaemia and hyperinsulinaemia, which would predict an exaggerated postprandial lipid response. However, even in the absence of these associated conditions, obese individuals may have up to three times higher postprandial TAG levels than non-obese control patients ${ }^{99-102}$, and an abnormal postprandial lipid pattern is a trait of abdominal obesity even without fasting hypertriacylglycerolaemia ${ }^{102}$. In a postprandial study of non-obese and obese subjects, Goldberg et al. ${ }^{103}$ reported a significant correlation between LPL activity and the postprandial TAG response only among the non-obese subjects. Obesity is associated with an exaggerated postprandial lipaemia, but a $10 \mathrm{~kg}$ weight decrease led to a reduction in chylomicron size but not in the number of particles $^{104}$.

Hypertriacylglycerolaemia. Subjects with fasting hypertriacylglycerolaemia are known to display exaggerated and prolonged postprandial lipid responses, with a fourfold increase in the half-life of circulating TRL, particularly those of intestinal origin, possibly due to a reduction in LPL activity. Elevated fasting TAG, by enhancing circulating VLDL particle concentration and thus promoting abnormal TRL accumulation postprandially, is the most important and common condition affecting postprandial lipaemia.

Insulin resistance. The insulin-resistant state is associated with a cluster of abnormalities in glucose and lipid homeostasis, including elevated levels of plasma fasting TAG, low plasma concentrations of HDL-cholesterol and an increased prevalence of small, dense $\mathrm{LDL}^{105}$. Metabolic defects include impaired NEFA metabolism, a saturation of the removal of TRL remnants and an increased hepatic secretion of VLDL particles ${ }^{106}$. In several studies, the degree of insulin sensitivity was a determinant of the postprandial lipaemic response among healthy adults independently of body mass index, waist-to-hip ratio, blood glucose level and the insulin effect on fasting plasma $\mathrm{TAG}^{107,108}$. In women and men, fasting insulin levels have been correlated with the degree of postprandial lipaemia ${ }^{100,102}$. The mechanisms are not entirely understood but are probably due to an aberrant insulinmediated suppression of hepatic VLDL production and fatty acid release from adipose tissue ${ }^{15}$.

Type 2 diabetes mellitus. Type 2 diabetes mellitus is associated with a marked increase in risk of CVD. A characteristic clinical feature of individuals with diabetes is the prevalence of a dyslipidaemia with elevated plasma levels of TAG, small, dense LDL particles and a low plasma HDLcholesterol concentrations ${ }^{109}$. Both fasting and postprandial plasma remnant lipoprotein-cholesterol levels were elevated $^{109-111}$. Interestingly, the impact of type 2 diabetes mellitus on lipoprotein phenotype and on risk of CHD is enhanced in women compared with men. Thus, women with type 2 diabetes mellitus have a higher proportion of small, dense LDL present that is dependent on the plasma TAG tertile ${ }^{12,113}$, and they have relatively higher plasma remnant lipoproteincholesterol levels than men ${ }^{114}$. Both parameters significantly contribute to the atherogenic lipoprotein phenotype seen in patients with type 2 diabetes mellitus. In addition, the premenopausal advantage in clearance of dietary lipid is not seen in premenopausal diabetic women ${ }^{115}$, and the oestrogen-associated advantage in the clearance of dietary lipid observed in non-diabetic postmenopausal women is not seen in postmenopausal diabetic women ${ }^{116}$.

\section{Genetic background}

The effect of several polymorphisms on postprandial lipoprotein metabolism have been studied. However, in the majority of studies described in this section, single-nucleotide polymorphisms have been studied, and few studies have performed a more comprehensive analysis involving haplotypes and multiple genes. A summary with the more recent studies is shown in Table 3.

Apo polymorphisms. Apo A-I is the main HDL protein and plays a crucial role in lipid metabolism. It is an in vivo activator of the enzyme lecithin-cholesterol acyltransferase $^{117}$ and an essential element of reverse cholesterol transport $^{118}$. These facts may be relevant to postprandial metabolism. Calabresi et al. ${ }^{119}$ showed that carriers of the rare apo A-I Milano mutation have a threefold higher greater postprandial lipaemia but that after correction for the different baseline TAG levels, it was similar to that of control subjects. In another study, carriers of the $A$ allele in the promoter region of apo A-I ( -76 base pairs G/A genotype), which occurs at a frequency of $0 \cdot 15-0 \cdot 20$ in white populations, have a greater postprandial increase in large TRL (35\%) and a smaller decrease in LDL-cholesterol (10\%) and apo $\mathrm{B}(8 \%)$ after the consumption of a fatty meal than do those with the G/G genotype ${ }^{120}$. The different postprandial responses observed could be due to changes in lipid absorption and/or clearance of TRL particles of intestinal origin, as indicated by the greater increase in apo B-48 (twofold) and large postprandial TRL-TAG concentrations, independently of baseline TAG plasma levels. 
Table 3. Recent genetic association studies on postprandial lipoprotein response

Gene/single-nucleotide polymorphism Study

Apo A5 / T-1131 (Jang et al. ${ }^{132}$ )

Apo E / E-2, E-3, E-4 (Cardona et al. ${ }^{151}$ )

FABP-2 / A54T (Dworatzek et al. ${ }^{164}$ )

LPL / HindIII, S447X (Lopez-Miranda et al. ${ }^{171}$ )

Hepatic lipase /-514C/T (Gomez et al. $\left.{ }^{174}\right)$

Microsomal triglyceride transfer protein / - $164 \mathrm{~T} / \mathrm{C}$ (Phillips et al. ${ }^{181}$ )

Scavenger receptor class B type I/ exon 1

(Perez-Martinez et al. ${ }^{179}$ )
Main results

The $C$ allele was found to be associated with greater increases in total chylomicron and VLDL triacylglycerol than was seen in subjects with the TT genotype

Patients with metabolic syndrome who do not have the E-3/3 genotype have a greater risk of hyperuricaemia and postprandial hypertriacylglycerolaemia after a fat overload

In this study, in which subjects were given three oral fat tolerance tests (butter, safflower oil, olive oil), the T54 group had increased chylomicron cholesterol levels only after the olive oil test

Carriers of the $\mathrm{H} 1$ allele (H1S447 and H1X447 genotypes) presented a lower postprandial lipaemic response than subjects with the H2S447 genotype

Subjects homozygous for the T allele showed a lower postprandial response of triacylglycerol-rich lipoprotein particles with a decrease in both total triacylglycerol and small and large triacylglycerol-rich lipoprotein-triacylgylcerols

No association was found between the $-164 \mathrm{~T} / \mathrm{C}$ polymorphism and the postprandial lipid profile

The presence of the 2 allele at the scavenger receptor class B type I polymorphism in exon 1 was associated with a faster clearance of small triacylglycerol-rich lipoprotein
Apo A-IV influences dietary fat absorption and chylomicron synthesis ${ }^{121}$, modulates the activation of LPL by apo C-II ${ }^{122}$ and activates lecithin-cholesterol acyltransferase ${ }^{123}$. The most common variant detected are the Gln360His and Thr347Ser polymorphisms ${ }^{124,125}$. Subjects with the His360 allele, which occurs at a frequency of $0.08-0.10$ in white populations, had a higher postprandial increase in small TRL-cholesterol, small TRL-TAG $(P<0.01)$ and large TRLTAG than $360 \mathrm{Gln} / \mathrm{Gln}$ subjects ${ }^{126}$, probably due to a delayed hepatic clearance of chylomicron remnants. The Thr347Ser polymorphism, which occurs at a frequency of $0 \cdot 18-0.22$ in white populations, also modulates the postprandial lipaemic response, so that carriers of the Ser347 allele presented a lower postprandial response $(-26 \%)$ in the TAG levels of chylomicron remnant particles associated with a higher postprandial response in the plasma levels of apo A-IV of chylomicrons $(70 \%)$ than did those homozygous for the Thr347 allele ${ }^{127}$.

Apo $A-V$ plays an important role in lipid metabolism by modulating hepatic VLDL synthesis and/or secretion, as well as TRL catabolism at the level of $\mathrm{LPL}^{128}$. Associations between T-1131C and Ser19 $\Rightarrow$ Trp polymorphisms and TAG concentrations have been found in different population samples ${ }^{129,130}$. In addition, The $\mathrm{C}$ allele of the $\mathrm{T}-1131 \mathrm{C}$ polymorphism, which occurs at a frequency of $0.20-0.25$ in white populations, was found to be associated with higher concentrations of plasma $\mathrm{TAG}^{131}$ and higher postprandial TAG $(+30 \%)^{132,133}$. This indicates that the effect of this polymorphism on postprandial lipoprotein response may be mediated, at less in part, by its effect on fasting TAG levels.

Aро $B$ is required for the assembly and secretion of chylomicrons in the small intestine and VLDL in the liver, and also acts as the ligand for the recognition of LDL by LDL receptor. Since apo B is the main protein of $\mathrm{LDL}$ and a major component of VLDL, it is to be expected that genetic variations at this locus could influence plasma cholesterol and/or TAG levels in both the fasting and postprandial states. The $\mathrm{XbaI}$ polymorphism, a silent mutation (ACC $\Rightarrow$ ACT) in exon $26^{134}$, was related to the interindividual variability observed during postprandial lipaemia. Thus, the frequent $\mathrm{X}$ allele is associated with a significantly increased postprandial response of retinyl palmitate $(50 \%)$ in all TRL fractions, independently of baseline TAG levels ${ }^{135}$. This mutation does not lead to an amino acid change at the affected codon and cannot have a direct functional effect. Moreover, the $\mathrm{D}$ allele at the three-codon (leucine-alanine-leucine) I/D polymorphism within the apo B signal peptide $^{136}$ was associated with a reduced postprandial lipid response in comparison with that of individuals homozygous for the I allele, thus suggesting that this signal peptide mutation may affect apo B secretion during the postprandial state. More recently, the association between postprandial NEFA concentrations and TRL has been reported to be influenced by this common deletion polymorphism ${ }^{137}$, which is also involved in the postprandial response ${ }^{138}$.

Apo $C$ - $I$ is a constituent of TRL and has been shown to displace apo E from TAG-rich emulsions and interfere with their hepatic clearance. Apo C-I also interferes with the binding of VLDL to the LDL-related protein receptor ${ }^{139}$ and to LDL receptors $^{140}$. The presence of the apo C-I 317-321ins allele, which occurs at a frequency of 0.30 in white populations, has been shown in vitro to increase the expression of apo CI by $50 \%{ }^{141}$. Thus, a direct inhibitory mechanism would most likely explain the high levels $(40 \%)$ of remnant lipoprotein-TAG and remnant lipoprotein-C observed in apo C-I 317321 ins/ins subjects ${ }^{142}$. This effect appeared to be recessive, with no obvious effect in heterozygous carriers.

Plasma apo C-III inhibits LPL and the binding of apo E-containing lipoproteins to its receptors. Five polymorphisms $(-641 \mathrm{C} / \mathrm{A},-630 \mathrm{G} / \mathrm{A},-625 \mathrm{~T} /$ deletion, $-482 \mathrm{C} / \mathrm{T}$, $-455 \mathrm{~T} / \mathrm{C}$ ) have been identified in the promoter region of this gene, all of which are in linkage disequilibrium with the SstI site in the $3^{\prime}$ untranslated region, distinguishing the $\mathrm{S} 1$ and $\mathrm{S} 2$ alleles. Recently, the raising effect of the $-482 \mathrm{C} / \mathrm{T}$ variant on plasma remnant particles has been shown to be confined to homozygous carriers of the $-482 \mathrm{~T}$ allele rather than Sst I polymorphic site ${ }^{142}$. It should be noted that a second variant, $-455 \mathrm{~T} / \mathrm{C}$, which was not evaluated in that study, is also present in the insulin response element, and would also be likely to show an association with remnant lipoprotein-TAG as it is in strong linkage disequilibrium with the $-482 \mathrm{C} / \mathrm{T}$ variant. In another study, homozygosity for the G allele at the apo C-III T2854G polymorphism were associated with an increase in the 
postprandial TAG response ${ }^{143}$. The GG homozygotes had $21 \%$ higher TAG area under the curve than the T/T homozygotes, and a $22 \%$ higher TAG value than $\mathrm{T} / \mathrm{G}$ heterozygotes.

Apo $E$ is a structural component of several lipoproteins and serves as a ligand for the LDL receptor and the LDL receptorrelated protein ${ }^{139,144}$. Therefore, apo E plays an important role in postprandial lipid metabolism by promoting the efficient uptake of TRL from the circulation ${ }^{145}$. However, such functions are not uniformly effective because apo $\mathrm{E}$ is present in the population in three main isoforms (E2, E3, E4), which determine apo $\mathrm{E}$ concentrations and differ in their affinity to bind to the specific receptors ${ }^{146,147}$. In fact, apo $\mathrm{E}$ isoforms are important determinants of postprandial lipaemia. It has been demonstrated that apo E-2 homozygous subjects have a delayed postprandial clearance due to the lowest affinity for TRL remnant receptor(s). Compared with apo E-3 homozygous patients, apo E-4 carriers tend to have an enhanced clearance of remnants ${ }^{148}$. However, several studies have found enhanced and/or prolonged postprandial lipid and apo responses in apo E-4 carriers ${ }^{149,150}$. Patients with the metabolic syndrome who do not have the E-3/3 genotype have a greater risk (odds ratio 6.2, CI 1.41-16.08) of hyperuricaemia and postprandial hypertriacylglycerolaemia after a fat over$\operatorname{load}^{151}$.

On the other hand, a polymorphism in the proximal promoter region of the apo E gene was recently described at position $-219 \mathrm{G} / \mathrm{T}^{152-154}$, which is associated with an increased risk of myocardial infarction ${ }^{154}$ and $\mathrm{CHD}^{155}$. The $-219 \mathrm{~T}$ allele was associated with decreased transcriptional activity ${ }^{153,154}$, decreased plasma apo E concentration both in the fasting and the postprandial state ${ }^{154,156}$ and a prolonged and enhanced postprandial lipaemic response $(50 \%$ increase for T/T homozygotes and $15 \%$ for $\mathrm{T} / \mathrm{G}$ heterozygotes) ${ }^{156}$.

Transport proteins. The intestinal fatty acid-binding protein-2 is located in the intestine and involved in long-chain fatty acid transport and metabolism ${ }^{157}$. A common alanine for threonine substitution at the $F A B P 2$ codon 54 (the A54T polymorphism), which occurs at a frequency of 0.28 in white populations, has been associated with hypertriacylglycerolaemia, obesity, hyperinsulinaemia and insulin resistance $^{158-160}$. The T54 allele is associated with a $41 \%$ increased postprandial lipaemia in obese ${ }^{161}$ and an $80 \%$ increase in diabetic ${ }^{162}$ subjects. However, not all studies have supported the associations with postprandial lipaemia ${ }^{163}$. It has been proposed that this association might depend on the type of fat ingested. Thus, in a recent study in which subjects were given three oral fat-tolerance tests (butter, safflower oil, olive oil), the T54 group showed increased chylomicron cholesterol levels only after the olive oil-containing test ${ }^{164}$.

The fatty acid transport proteins have been implicated in the facilitated cellular uptake of NEFA, thus having the potential to regulate local and systemic NEFA concentrations and metabolism. Hypothesising that genetic variation within the fatty acid transport protein genes may affect postprandial metabolism, the G/A substitution at position 48 in intron 8 of the fatty acid transport-1 gene was studied. Although fasting plasma TAG concentrations were no different, male A/A individuals had significantly higher postprandial TAG concentrations and ratio of VLDL1 (Sf 60-400 apo B-100) to VLDL2 (Sf 20-60 apo B-100) compared with male individuals with the $\mathrm{G} / \mathrm{A}$ and $\mathrm{G} / \mathrm{G}$ variations ${ }^{165}$.
Enzymes and receptor polymorphisms. The LPL gene is the obvious candidate for studies of postprandial lipaemia, in as much as it codes for the single protein hydrolysing TAG from chylomicrons and large VLDL. It also enhances the binding of apo E-containing lipoproteins to the LDL receptor-related protein, thus affecting the catabolism of chylomicron remnants ${ }^{166}$. Talmud et al. ${ }^{167}$ have studied the interaction between the functional variants involving the LPL-93T/G promoter polymorphism and the LPL D9N substitution, which were identified with a combined population frequency of 3-6\%. Carriers of the haplotype constituting the rare LPL-93G variant (presumably higher transcriptional activity) and the common LPL9N variant (presumably secretion-defective LPL protein) exhibited higher plasma TAG levels after a meal than did carriers of other haplotypes $^{167}$.

The LPL A291S residue variant affects the specific activity of the enzyme and has a carrier frequency of $4-6 \%{ }^{168}$. Two studies show that carriers of this variant have a significantly higher ( $41 \%$ higher area under the curve) postprandial triacylglycerolaemia ${ }^{169,170}$. In a recent study, the association between LPL Hind III (H1/H2) and Ser447-stop (S447X) polymorphisms and postprandial lipaemia was analysed. Thus, carriers of the H1X447 genotypes presented a lower postprandial lipaemic response (42\% lower area under the curve) than subjects with the $\mathrm{H} 2 \mathrm{~S} 447$ genotype (homozygote for the $\mathrm{H} 2$ allele of the LPL Hind III polymorphism and S447 allele), independently of baseline TAG levels ${ }^{171}$.

Hepatic lipase has been implicated in the removal of remnant lipoproteins. The promoter of the hepatic lipase gene contains several single-nucleotide polymorphisms ${ }^{172}$. The rare variant of the $-480 \mathrm{C} / \mathrm{T}$ (also called $-514 \mathrm{C} / \mathrm{T}$ ) polymorphism, present in $0 \cdot 15-0 \cdot 21$ of the white population, has been associated with lower hepatic lipase activity. Jansen et al. observed that this polymorphism did not seem to affect total postprandial triacylglycerolaemia but did affect the retention of a specific lipoprotein subspecies in the postprandial state, the LpCIII:B particles, which are likely to reflect remnant lipoproteins ${ }^{173}$. However, in a recent study, subjects homozygous for the $\mathrm{T}$ allele showed a lower postprandial response of TRL particles (47\% lower area under the curve) with a decrease in both total TAG and small and large TRL-TAG postprandial responses ${ }^{174}$.

Microsomal triglyceride transfer protein plays a role in the formation of VLDL in the liver and of chylomicrons in the intestine by transferring core lipids to the apo B molecule. Common polymorphisms have been described at position $-493 \mathrm{G} / \mathrm{T},-400 \mathrm{~A} / \mathrm{T}$ and $-164 \mathrm{~T} / \mathrm{C}$ in the promoter region for the microsomal triglyceride transfer protein. Homozygous carriers of the rare MTP-493T variant, which is associated with higher transcriptional activity of the gene in vitro ${ }^{175}$, showed a markedly elevated accumulation of small apo B-48-containing lipoproteins in the postprandial state in healthy subjects and individuals with type 2 diabetes ${ }^{175,176}$. The $-400 \mathrm{~A} / \mathrm{T}$ substitution gave very similar lipoprotein results, but there was significant linkage disequilibrium between the two polymorphisms.

Scavenger receptor class B type I is one of the intestinal proteins involved in the absorption of dietary cholesterol and triacylglycerols, suggesting that it may also play a role in postprandial responses ${ }^{177,178}$. Thus, the presence of the 2 allele at 
the scavenger receptor class B type I polymorphism in exon 1 was associated with a faster clearance of small TRL, probably related to a more rapid hepatic uptake ${ }^{179}$.

\section{Conclusion}

As reviewed, postprandial lipid and lipoprotein metabolism is modulated by background dietary pattern as well as meal composition and also by several lifestyle conditions (physical activity, smoking, alcohol consumption), physiological factors (age, gender, menopausal status) and pathological conditions (hypertriacylglycerolaemia, diabetes mellitus, insulin resistance, central obesity). Although these above-mentioned factors do influence postprandial lipid response and metabolism, the weight of their respective effect is variable, as illustrated in Table 4. The most important ones appear to be the amount of meal fat and other components (carbohydrate, protein, alcohol, fibre), physical exercise, tobacco use, gender, pre-existing hypertriacylglycerolaemia, obesity and insulin resistance/type 2 diabetes.

The postprandial lipid response has been shown to be modified by polymorphisms within the genes for apo A-I, E, B, C-I, C-III, A-IV and A-V, LPL, hepatic lipase, fatty acid-binding protein-2, the fatty acid transport proteins, microsomal triglyceride transfer protein and scavenger receptor class B type I. Nevertheless, most previous and current studies have been conducted using the simplest scenarios, that is, one single dietary component, one single nucleotide polymorphism and one single risk factor. We have to evolve toward more realistic situations involving interactions between multiple genes, dietary components and risk factors ${ }^{180}$. This will require large genetic epidemiological studies and intervention studies involving groups of individuals selected for specific genotype combinations and phenotypic characteristics and subjected to controlled dietary intervention protocols in order to establish

Table 4. Factors affecting postprandial lipid metabolism

\begin{tabular}{ll}
\hline & $\begin{array}{l}\text { Extent of change in } \\
\text { postprandial lipaemia }\end{array}$ \\
& \\
\hline Dietary factors & \\
Amount of fat (meal) & ++ \\
Type of fat (meal) & $+/-$ (depending on type of fat) \\
Type of fat (habitual diet) & $+/-$ (depending on type of fat) \\
Carbohydrates & ++ \\
Protein (meal) & No / - (depending on type of protein) \\
Alcohol & ++ \\
Fibre & No / - (depending on type of fibre) \\
Lifestyle factors & -- \\
Physical exercise & ++ \\
Tobacco use & \\
Physiological factors & + (males) \\
Gender & + \\
Age & + (postmenauposal status) \\
Menopausal status & \\
Physiopathology & +++ \\
Fasting triacylglycerolaemia & ++ \\
Central obesity & ++ \\
Insulin resistance/type & \\
2 diabetes & \\
\hline
\end{tabular}

,,++++++ , very important, important or moderate increase;,--- , important or moderate reduction; No, no noticeable change. the specific gene-diet interactions. Such kind of studies are being conducted through European consortia such as the LIPGENE project (www.lipgene.tcd.ie).

Nutrigenetics examines the effect of genetic variation on the interaction between diet and disease as several risk factors. This includes identifying and characterising gene variants and factors associated with or responsible for differential responses to nutrients or the postprandial response. One of the goal of nutrigenetics is to generate recommendations regarding the risks and benefits of specific diets or dietary components to the individual. It has been also termed 'personalised nutrition' or 'individualised nutrition'.

Intervention and observational studies that attempt to examine gene-diet interactions need to include repeated sampling and measurement to provide an accurate measure of the phenotypes. To elucidate gene-environment interactions, and specifically gene-diet interactions, we need population sizes several orders of magnitude larger than those currently used for common multifactorial diseases. This will require the creation of international consortiums built along the models of the EPIC study or the Human Genome Project. Complex phenotype and genotype interactions require an analysis of their combined effects. The information will need to be incorporated into predictive models that can be used clinically to improve disease assessment and prevention. This will be probably happen within the umbrella of bioinformatics or computational biology.

\section{Acknowledgements}

This work was commissioned by the Nutritional Value of Food Task Force of the European branch of the International Life Sciences Institute (ILSI Europe). Industry members of this task force are Nestlé, Danone, Südzucker and Danisco. For further information about ILSI Europe, email info@ ilsieurope.be or call +32 27710014. The opinions expressed in this article are those of the authors and do not necessarily represent the views of ILSI Europe.

\section{References}

1. Cohn JS, McNamara JR, Cohn SD, Ordovas JM \& Schaefer EJ (1988) Postprandial plasma lipoprotein changes in human subjects of different ages. J Lipid Res 29, 469-479.

2. Zilversmit DB (1979) Atherogenesis: a postprandial phenomenon. Circulation 60, 473-485.

3. Groot PH, van Stiphout WA, Krauss XH, et al. (1991) Postprandial lipoprotein metabolism in normolipidemic men with and without coronary artery disease. Arterioscler Thromb 11, 653-662.

4. Patsch JR, Miesenbock G, Hopferwieser T, Muhlberger V, Knapp E, Dunn JK, Gotto AM Jr \& Patsch W (1992) Relation of triglyceride metabolism and coronary artery disease. Studies in the postprandial state. Arterioscler Thromb 12, 1336-1345.

5. Karpe F, Tornvall P, Olivecrona T, Steiner G, Carlson LA \& Hamsten A (1993) Composition of human low density lipoprotein: effects of postprandial triglyceride-rich lipoproteins, lipoprotein lipase, hepatic lipase and cholesteryl ester transfer protein. Atherosclerosis 98, 33-49.

6. Meyer E, Westerveld HT, de Ruyter-Meijstek FC, van Greevenbroek MM, Rienks R, van Rijn HJ, Erkelens DW \& de 
Bruin TW (1996) Abnormal postprandial apolipoprotein B-48 and triglyceride responses in normolipidemic women with greater than $70 \%$ stenotic coronary artery disease: a case-control study. Atherosclerosis 124, 221-235.

7. Ginsberg HN, Jones J, Blaner WS, Thomas A, Karmally W, Fields L, Blood D \& Begg MD (1995) Association of postprandial triglyceride and retinyl palmitate responses with newly diagnosed exercise-induced myocardial ischemia in middle-aged men and women. Arterioscler Thromb Vasc Biol 15, 1829-1838.

8. Ryu JE, Howard G, Craven TE, Bond MG, Hagaman AP \& Crouse JR 3rd (1992) Postprandial triglyceridemia and carotid atherosclerosis in middle-aged subjects. Stroke 23, 823-828.

9. Karpe F, de Faire U, Mercuri M, Bond MG, Hellenius ML \& Hamsten A (1998) Magnitude of alimentary lipemia is related to intima-media thickness of the common carotid artery in middle-aged men. Atherosclerosis 141, 307-314.

10. Boquist S, Ruotolo G, Tang R, Bjorkegren J, Bond MG, de Faire U, Karpe F \& Hamsten A (1999) Alimentary lipemia, postprandial triglyceride-rich lipoproteins, and common carotid intima-media thickness in healthy, middle-aged men. Circulation 100, 723-728.

11. Hamsten A, Silveira A, Boquist S, Tang R, Bond MG, de Faire U \& Bjorkegren J (2005) The apolipoprotein CI content of triglyceride-rich lipoproteins independently predicts early atherosclerosis in healthy middle-aged men. J Am Coll Cardiol 45, $1013-1017$.

12. Uiterwaal CS, Grobbee DE, Witteman JC, van Stiphout WA, Krauss XH, Havekes LM, de Bruijn AM, van Tol A \& Hofman A (1994) Postprandial triglyceride response in young adult men and familial risk for coronary atherosclerosis. Ann Intern Med 121, 576-583.

13. Tiret L, Gerdes C, Murphy MJ, Dallongeville J, Nicaud V, O'Reilly DS, Beisiegel U \& De Backer G (2000) Postprandial response to a fat tolerance test in young adults with a paternal history of premature coronary heart disease - the EARS II study (European Atherosclerosis Research Study). Eur J Clin Invest 30, 578-585.

14. Phillips NR, Waters D \& Havel RJ (1993) Plasma lipoproteins and progression of coronary artery disease evaluated by angiography and clinical events. Circulation 88, 2762-2770.

15. Karpe F (1999) Postprandial lipoprotein metabolism and atherosclerosis. J Intern Med 246, 341-355.

16. Speidel MT, Booyse FM, Abrams A, Moore MA \& Chung BH (1990) Lipolyzed hypertriglyceridemic serum and triglyceriderich lipoprotein cause lipid accumulation in and are cytotoxic to cultured human endothelial cells. High density lipoproteins inhibit this cytotoxicity. Thromb Res 58, 251-264.

17. Vogel RA, Corretti MC \& Plotnick GD (1997) Effect of a single high-fat meal on endothelial function in healthy subjects. Am J Cardiol 79, 350-354.

18. Doi H, Kugiyama K, Oka H, Sugiyama S, Ogata N, Koide SI, Nakamura SI \& Yasue H (2000) Remnant lipoproteins induce proatherothrombogenic molecules in endothelial cells through a redox-sensitive mechanism. Circulation 102, 670-676.

19. Griffin BA (1999) Lipoprotein atherogenicity: an overview of current mechanisms. Proc Nutr Soc 58, 163-169.

20. Miller GJ (1998) Postprandial lipaemia and haemostatic factors. Atherosclerosis 141, Suppl. 1, S47-S51.

21. Sanders TA, Oakley FR, Cooper JA \& Miller GJ (2001) Influence of a stearic acid-rich structured triacylglycerol on postprandial lipemia, factor VII concentrations, and fibrinolytic activity in healthy subjects. Am J Clin Nutr 73, 715-721.

22. Tholstrup T, Miller GJ, Bysted A \& Sandstrom B (2003) Effect of individual dietary fatty acids on postprandial activation of blood coagulation factor VII and fibrinolysis in healthy young men. Am J Clin Nutr 77, 1125-1132.
23. Broijersen A, Karpe F, Hamsten A, Goodall AH \& Hjemdahl P (1998) Alimentary lipemia enhances the membrane expression of platelet P-selectin without affecting other markers of platelet activation. Atherosclerosis 137, 107-113.

24. Hyson DA, Paglieroni TAG, Wun T \& Rutledge JC (2002) Postprandial lipemia is associated with platelet and monocyte activation and increased monocyte cytokine expression in normolipemic men. Clin Appl Thromb Hemost 8, 147-155.

25. Cohen JC \& Berger GM (1990) Effects of glucose ingestion on postprandial lipemia and triglyceride clearance in humans. $J$ Lipid Res 31, 597-602.

26. van Tol A, van der Gaag MS, Scheek LM, van Gent T \& Hendriks HF (1998) Changes in postprandial lipoproteins of low and high density caused by moderate alcohol consumption with dinner. Atherosclerosis 141, Suppl. 1, S101-S103.

27. Williams CM (1998) Dietary interventions affecting chylomicron and chylomicron remnant clearance. Atherosclerosis 141, Suppl. 1, S87-S92.

28. Tinker LF, Parks EJ, Behr SR, Schneeman BO \& Davis PA (1999) (n-3) fatty acid supplementation in moderately hypertriglyceridemic adults changes postprandial lipid and apolipoprotein B responses to a standardized test meal. J Nutr 129, 1126-1134.

29. Cohen JC, Noakes TD \& Benade AJ (1988) Serum triglyceride responses to fatty meals: effects of meal fat content. Am J Clin Nutr 47, 825-827.

30. Dubois C, Armand M, Azais-Braesco V, et al. (1994) Effects of moderate amounts of emulsified dietary fat on postprandial lipemia and lipoproteins in normolipidemic adults. Am J Clin Nutr 60, 374-382.

31. Murphy MC, Isherwood SG, Sethi S, Gould BJ, Wright JW, Knapper JA \& Williams CM (1995) Postprandial lipid and hormone responses to meals of varying fat contents: modulatory role of lipoprotein lipase? Eur J Clin Nutr 49, 578-588.

32. Dubois C, Beaumier G, Juhel C, Armand M, Portugal H, Pauli AM, Borel P, Latge C \& Lairon D (1998) Effects of graded amounts $(0-50 \mathrm{~g})$ of dietary fat on postprandial lipemia and lipoproteins in normolipidemic adults. Am J Clin Nutr 67, $31-38$.

33. Jackson KG, Robertson MD, Fielding BA, Frayn KN \& Williams CM (2002) Olive oil increases the number of triacylglycerol-rich chylomicron particles compared with other oils: an effect retained when a second standard meal is fed. Am J Clin Nutr 76, 942-949.

34. Williams CM, Moore F, Morgan L \& Wright J (1992) Effects of n-3 fatty acids on postprandial triacylglycerol and hormone concentrations in normal subjects. $\mathrm{Br} J \mathrm{Nutr}$ 68, 655-666.

35. Roche HM, Zampelas A, Jackson KG, Williams CM \& Gibney MJ (1998) The effect of test meal monounsaturated fatty acid: saturated fatty acid ratio on postprandial lipid metabolism. $\mathrm{Br} J$ Nutr 79, 419-424.

36. Thomsen C, Rasmussen O, Lousen T, Holst JJ, Fenselau S, Schrezenmeir J \& Hermansen K (1999) Differential effects of saturated and monounsaturated fatty acids on postprandial lipemia and incretin responses in healthy subjects. Am J Clin Nutr 69, 1135-1143.

37. Mekki N, Charbonnier M, Borel P, Leonardi J, Juhel C, Portugal H \& Lairon D (2002) Butter differs from olive oil and sunflower oil in its effects on postprandial lipemia and triacylglycerol-rich lipoproteins after single mixed meals in healthy young men. J Nutr 132, 3642-3649.

38. Sakr SW, Attia N, Haourigui M, Paul JL, Soni T, Vacher D \& Girard-Globa A (1997) Fatty acid composition of an oral load affects chylomicron size in human subjects. Br J Nutr 77, $19-31$. 
39. Armand M, Pasquier B, Andre M, et al. (1999) Digestion and absorption of 2 fat emulsions with different droplet sizes in the human digestive tract. Am J Clin Nutr 70, 1096-1106.

40. Cabezas MC, de Bruin TW, Jansen H, Kock LA, Kortlandt W \& Erkelens DW (1993) Impaired chylomicron remnant clearance in familial combined hyperlipidemia. Arterioscler Thromb 13, 804-814.

41. Lichtenstein AH, Ausman LM, Carrasco W, Jenner JL, Gualtieri LJ, Goldin BR, Ordovas JM \& Schaefer EJ (1993) Effects of canola, corn, and olive oils on fasting and postprandial plasma lipoproteins in humans as part of a National Cholesterol Education Program Step 2 diet. Arterioscler Thromb 13, $1533-1542$.

42. Tholstrup T, Sandstrom B, Bysted A \& Holmer G (2001) Effect of 6 dietary fatty acids on the postprandial lipid profile, plasma fatty acids, lipoprotein lipase, and cholesterol ester transfer activities in healthy young men. Am J Clin Nutr 73, 198-208.

43. Zampelas A, Peel AS, Gould BJ, Wright J \& Williams CM (1994) Polyunsaturated fatty acids of the $n-6$ and $n-3$ series: effects on postprandial lipid and apolipoprotein levels in healthy men. Eur J Clin Nutr 48, 842-848.

44. Jackson KG, Zampelas A, Knapper JM, Culverwell CC, Wright J, Gould BJ \& Williams CM (1999) Lack of influence of test meal fatty acid composition on the contribution of intestinally-derived lipoproteins to postprandial lipaemia. Br J Nutr 81, 51-57.

45. Vessby B, Unsitupa M, Hermansen K, et al. (2001) Substituting dietary saturated for monounsaturated fat impairs insulin sensitivity in healthy men and women: the KANWU Study. Diabetologia 44, 312-319.

46. Burdge GC, Powell J \& Calder PC (2006) Lack of effect of meal fatty acid composition on postprandial lipid, glucose and insulin responses in men and women aged 50-65 years consuming their habitual diets. Br J Nutr 96, 489-500.

47. Jensen MM, Christensen MS \& Hoy CE (1994) Intestinal absorption of octanoic, decanoic, and linoleic acids: effect of triglyceride structure. Ann Nutr Metab 38, 104-116.

48. Sanders TA, de Grassi T, Miller GJ \& Morrissey JH (2000) Influence of fatty acid chain length and cis/trans isomerization on postprandial lipemia and factor VII in healthy subjects (postprandial lipids and factor VII). Atherosclerosis 149, 413-420.

49. Sanders TA, Berry SE \& Miller GJ (2003) Influence of triacylglycerol structure on the postprandial response of factor VII to stearic acid-rich fats. Am J Clin Nutr 77, 777-782.

50. Jackson KG, Robertson MD, Fielding BA, Frayn KN \& Williams CM (2002) Measurement of apolipoprotein B-48 in the Svedberg flotation rate $(\mathrm{S}(\mathrm{f}))>400, \mathrm{~S}(\mathrm{f}) 60-400$ and S(f) 20-60 lipoprotein fractions reveals novel findings with respect to the effects of dietary fatty acids on triacylglycerolrich lipoproteins in postmenopausal women. Clin Sci (Lond) 103, 227-237.

51. Jackson KG, Wolstencroft EJ, Bateman PA, Yaqoob P \& Williams CM (2005) Greater enrichment of triacylglycerolrich lipoproteins with apolipoproteins $\mathrm{E}$ and $\mathrm{C}$-III after meals rich in saturated fatty acids than after meals rich in unsaturated fatty acids. Am J Clin Nutr 81, 25-34.

52. Black IL, Roche HM, Tully AM \& Gibney MJ (2002) Acuteon-chronic effects of fatty acids on intestinal triacylglycerolrich lipoprotein metabolism. Br J Nutr 88, 661-669.

53. Roche HM, Zampelas A, Knapper JM, et al. (1998) Effect of long-term olive oil dietary intervention on postprandial triacylglycerol and factor VII metabolism. Am J Clin Nutr 68, 552-560.

54. Weintraub MS, Zechner R, Brown A, Eisenberg S \& Breslow JL (1988) Dietary polyunsaturated fats of the W-6 and W-3 series reduce postprandial lipoprotein levels. Chronic and acute effects of fat saturation on postprandial lipoprotein metabolism. J Clin Invest 82, 1884-1893.

55. Zampelas A, Roche H, Knapper JM, et al. (1998) Differences in postprandial lipaemic response between Northern and Southern Europeans. Atherosclerosis 139, 83-93.

56. Silva KD, Kelly CN, Jones AE, Smith RD, Wootton SA, Miller GJ \& Williams CM (2003) Chylomicron particle size and number, factor VII activation and dietary monounsaturated fatty acids. Atherosclerosis 166, 73-84.

57. Rivellese AA, Maffettone A, Vessby B, Uusitupa M, Hermansen K, Berglund L, Louheranta A, Meyer BJ \& Riccardi G (2003) Effects of dietary saturated, monounsaturated and n-3 fatty acids on fasting lipoproteins, LDL size and post-prandial lipid metabolism in healthy subjects. Atherosclerosis 167, 149-158.

58. Sanders TA, Oakley FR, Crook D, Cooper JA \& Miller GJ (2003) High intakes of trans monounsaturated fatty acids taken for 2 weeks do not influence procoagulant and fibrinolytic risk markers for CHD in young healthy men. Br J Nutr 89, 767-776.

59. Roche HM \& Gibney MJ (1996) Postprandial triacylglycerolaemia: the effect of low-fat dietary treatment with and without fish oil supplementation. Eur J Clin Nutr 50, 617-624.

60. Khan S, Minihane AM, Talmud PJ, Wright JW, Murphy MC, Williams CM \& Griffin BA (2002) Dietary long-chain n-3 PUFAs increase LPL gene expression in adipose tissue of subjects with an atherogenic lipoprotein phenotype. J Lipid Res 43, 979-985.

61. Park Y \& Harris WS (2003) Omega-3 fatty acid supplementation accelerates chylomicron triglyceride clearance. J Lipid Res 44, 455-463.

62. Finnegan YE, Minihane AM, Leigh-Firbank EC, Kew S, Meijer GW, Muggli R, Calder PC \& Williams CM (2003) Plant- and marine-derived n-3 polyunsaturated fatty acids have differential effects on fasting and postprandial blood lipid concentrations and on the susceptibility of LDL to oxidative modification in moderately hyperlipidemic subjects. Am J Clin Nutr 77, 783-795.

63. Harris WS \& Muzio F (1993) Fish oil reduces postprandial triglyceride concentrations without accelerating lipid-emulsion removal rates. Am J Clin Nutr 58, 68-74.

64. Westphal S, Orth M, Ambrosch A, Osmundsen K \& Luley C (2000) Postprandial chylomicrons and VLDLs in severe hypertriacylglycerolemia are lowered more effectively than are chylomicron remnants after treatment with n-3 fatty acids. Am J Clin Nutr 71, 914-920.

65. Harris WS, Connor WE, Illingworth DR, Rothrock DW \& Foster DM (1990) Effects of fish oil on VLDL triglyceride kinetics in humans. J Lipid Res 31, 1549-1558.

66. Nozaki S, Garg A, Vega GL \& Grundy SM (1991) Postheparin lipolytic activity and plasma lipoprotein response to omega-3 polyunsaturated fatty acids in patients with primary hypertriglyceridemia. Am J Clin Nutr 53, 638-642.

67. Harris WS, Lu G, Rambjor GS, Walen AI, Ontko JA, Cheng Q \& Windsor SL (1997) Influence of n-3 fatty acid supplementation on the endogenous activities of plasma lipases. Am J Clin Nutr 66, 254-260.

68. Parks EJ, Krauss RM, Christiansen MP, Neese RA \& Hellerstein MK (1999) Effects of a low-fat, high-carbohydrate diet on VLDL-triglyceride assembly, production, and clearance. J Clin Invest 104, 1087-1096.

69. Roche HM (1999) Dietary carbohydrates and triacylglycerol metabolism. Proc Nutr Soc 58, 201-207.

70. Grant KI, Marais MP \& Dhansay MA (1994) Sucrose in a lipidrich meal amplifies the postprandial excursion of serum and 
lipoprotein triglyceride and cholesterol concentrations by decreasing triglyceride clearance. Am J Clin Nutr 59, 853-860.

71. Harbis A, Defoort C, Narbonne H, et al. (2001) Acute hyperinsulinism modulates plasma apolipoprotein B-48 triglyceriderich lipoproteins in healthy subjects during the postprandial period. Diabetes 50, 462-469.

72. Harbis A, Perdreau S, Vincent-Baudry S, et al. (2004) Glycemic and insulinemic meal responses modulate postprandial hepatic and intestinal lipoprotein accumulation in obese, insulin-resistant subjects. Am J Clin Nutr 80, 896-902.

73. Cara L, Dubois C, Borel P, Armand M, Senft M, Portugal H, Pauli AM, Bernard PM \& Lairon D (1992) Effects of oat bran, rice bran, wheat fiber, and wheat germ on postprandial lipemia in healthy adults. Am J Clin Nutr 55, 81-88.

74. Lia A, Andersson H, Mekki N, Juhel C, Senft M \& Lairon D (1997) Postprandial lipemia in relation to sterol and fat excretion in ileostomy subjects given oat-bran and wheat test meals. Am J Clin Nutr 66, 357-365.

75. Higashi K, Abata S, Iwamoto N, Ogura M, Yamashita T, Ishikawa O, Ohslzu F \& Nakamura H (2001) Effects of soy protein on levels of remnant-like particles cholesterol and vitamin $\mathrm{E}$ in healthy men. J Nutr Sci Vitaminol (Tokyo) 47, 283-288.

76. Westphal S, Taneva E, Kastner S, Martens-Lobenhoffer J, Bode-Boger S, Kropf S, Dierkes J \& Luley C (2006) Endothelial dysfunction induced by postprandial lipemia is neutralized by addition of proteins to the fatty meal. Atherosclerosis 185, 313-319.

77. Mamo JC, James AP, Soares MJ, Griffiths DG, Purcell K \& Schwenke JL (2005) A low-protein diet exacerbates postprandial chylomicron concentration in moderately dyslipidaemic subjects in comparison to a lean red meat protein-enriched diet. Eur J Clin Nutr 59, 1142-1148.

78. Hardman AE \& Aldred HE (1995) Walking during the postprandial period decreases alimentary lipaemia. $J$ Cardiovasc Risk 2, 71-78.

79. Tsetsonis NV \& Hardman AE (1996) Reduction in postprandial lipemia after walking: influence of exercise intensity. Med Sci Sports Exerc 28, 1235-1242.

80. Tsetsonis NV \& Hardman AE (1996) Effects of low and moderate intensity treadmill walking on postprandial lipaemia in healthy young adults. Eur J Appl Physiol Occup Physiol 73, 419-426.

81. Hardman AE (1998) The influence of exercise on postprandial triacylglycerol metabolism. Atherosclerosis 141, Suppl. 1, S93-S100.

82. Thomas TR, Horner KE, Langdon MM, Zhang JQ, Krul ES, Sun GY \& Cox RH (2001) Effect of exercise and mediumchain fatty acids on postprandial lipemia. J Appl Physiol 90, $1239-1246$.

83. Sady SP, Thompson PD, Cullinane EM, Kantor MA, Domagala E \& Herbert PN (1986) Prolonged exercise augments plasma triglyceride clearance. JAMA 256, 2552-2555.

84. Ferguson MA, Alderson NL, Trost SG, Essig DA, Burke JR \& Durstine JL (1998) Effects of four different single exercise sessions on lipids, lipoproteins, and lipoprotein lipase. J Appl Physiol 85, 1169-1174.

85. Zhang JQ, Smith B, Langdon MM, Messimer HL, Sun GY, Cox RH, James-Kracke M \& Thomas TR (2002) Changes in LPLa and reverse cholesterol transport variables during 24-h postexercise period. Am J Physiol Endocrinol Metab 283, E267-E274.

86. Petitt DS \& Cureton KJ (2003) Effects of prior exercise on postprandial lipemia: a quantitative review. Metabolism 52, 418-424.

87. Gill JM, Mees GP, Frayn KN \& Hardman AE (2001) Moderate exercise, postprandial lipaemia and triacylglycerol clearance. Eur J Clin Invest 31, 201-207.
88. Smith BK, Sun GY, Donahue OM \& Thomas TR (2004) Exercise plus n-3 fatty acids: additive effect on postprandial lipemia. Metabolism 53, 1365-1371.

89. Axelsen M, Eliasson B, Joheim E, Lenner RA, Taskinen MR \& Smith U (1995) Lipid intolerance in smokers. J Intern Med 237, 449-455.

90. Mero N, Syvanne M, Eliasson B, Smith U \& Taskinen MR (1997) Postprandial elevation of ApoB-48-containing triglyceride-rich particles and retinyl esters in normolipemic males who smoke. Arterioscler Thromb Vasc Biol 17, 2096-2102.

91. Sharrett AR, Heiss G, Chambless LE, Boerwinkle E, Coady SA, Folsom AR \& Patsch W (2001) Metabolic and lifestyle determinants of postprandial lipemia differ from those of fasting triglycerides: the Atherosclerosis Risk In Communities (ARIC) study. Arterioscler Thromb Vasc Biol 21, 275-281.

92. Fielding BA, Reid G, Grady M, Humphreys SM, Evans K \& Frayn KN (2000) Ethanol with a mixed meal increases postprandial triacylglycerol but decreases postprandial non-esterified fatty acid concentrations. Br J Nutr 83, 597-604.

93. Siler SQ, Neese RA, Parks EJ \& Hellerstein MK (1998) VLDL-triglyceride production after alcohol ingestion, studied using [2-13C1] glycerol. J Lipid Res 39, 2319-2328.

94. Pownall HJ, Ballantyne CM, Kimball KT, Simpson SL, Yeshurun D \& Gotto AM Jr (1999) Effect of moderate alcohol consumption on hypertriglyceridemia: a study in the fasting state. Arch Intern Med 159, 981-987.

95. Couch SC, Isasi CR, Karmally W, et al. (2000) Predictors of postprandial triacylglycerol response in children: the Columbia University Biomarkers Study. Am J Clin Nutr 72, 1119-1127.

96. Jackson KG, Knapper-Francis JM, Morgan LM, Webb DH, Zampelas A \& Williams CM (2003) Exaggerated postprandial lipaemia and lower post-heparin lipoprotein lipase activity in middle-aged men. Clin Sci (Lond) 105, 457-466.

97. van Beek AP, de Ruijter-Heijstek FC, Erkelens DW \& de Bruin TW (1999) Menopause is associated with reduced protection from postprandial lipemia. Arterioscler Thromb Vasc Biol 19, 2737-2741.

98. Ossewaarde ME, Dallinga-Thie GM, Bots ML, van der Schouw YT, Rabelink TJ, Grobbee DE \& Westerveld HT (2003) Treatment with hormone replacement therapy lowers remnant lipoprotein particles in healthy postmenopausal women: results from a randomized trial. Eur J Clin Invest 33, 376-382.

99. Lewis GF, O’Meara NM, Soltys PA, Blackman JD, Iverius PH, Druetzler AF, Getz GS \& Polonsky KS (1990) Postprandial lipoprotein metabolism in normal and obese subjects: comparison after the vitamin A fat-loading test. J Clin Endocrinol Metab 71, 1041-1050.

100. Couillard C, Bergeron N, Prud'homme D, Bergeron J, Tremblay A, Bouchard C, Mauriege P \& Despres JP (1998) Postprandial triglyceride response in visceral obesity in men. Diabetes 47, 953-960.

101. Hadjadj S, Paul JL, Meyer L, Durlach V, Verges B, Ziegler O, Drouin P \& Guerci B (1999) Delayed changes in postprandial lipid in young normolipidemic men after a nocturnal vitamin A oral fat load test. J Nutr 129, 1649-1655.

102. Mekki N, Christofilis MA, Charbonnier M, et al. (1999) Influence of obesity and body fat distribution on postprandial lipemia and triglyceride-rich lipoproteins in adult women. $J$ Clin Endocrinol Metab 84, 184-191.

103. Goldberg IJ, Vanni-Reyes T, Ramakrishnan S, Holleran S \& Ginsberg HN (2000) Circulating lipoprotein profiles are modulated differently by lipoprotein lipase in obese humans. J Cardiovasc Risk 7, 41-47.

104. James AP, Watts GF, Barrett PH, Smith D, Pal S, Chan DC \& Mamo JC (2003) Effect of weight loss on postprandial lipemia and low-density lipoprotein receptor binding in overweight men. Metabolism 52, 136-141. 
105. Reaven G (2002) Metabolic syndrome: pathophysiology and implications for management of cardiovascular disease. Circulation 106, 286-288.

106. Taskinen MR (2002) Diabetic dyslipidemia. Atheroscler Suppl 3, 47-51.

107. Jeppesen J, Hollenbeck CB, Zhou MY, Coulston AM, Jones C, Chen YD \& Reaven GM (1995) Relation between insulin resistance, hyperinsulinemia, postheparin plasma lipoprotein lipase activity, and postprandial lipemia. Arterioscler Thromb Vasc Biol 15, 320-324.

108. Boquist S, Hamsten A, Karpe F \& Ruotolo G (2000) Insulin and non-esterified fatty acid relations to alimentary lipaemia and plasma concentrations of postprandial triglyceride-rich lipoproteins in healthy middle-aged men. Diabetologia 43, $185-193$.

109. Haffner SM (2002) Lipoprotein disorders associated with type 2 diabetes mellitus and insulin resistance. Am J Cardiol 90, $55 \mathrm{i}-61 \mathrm{i}$.

110. Hirany S, O'Byrne D, Devaraj S \& Jialal I (2000) Remnantlike particle-cholesterol concentrations in patients with type 2 diabetes mellitus and end-stage renal disease. Clin Chem 46, 667-672.

111. Hirano T, Yoshino G, Kashiwazaki K \& Adachi M (2001) Doxazosin reduces prevalence of small dense low density lipoprotein and remnant-like particle cholesterol levels in nondiabetic and diabetic hypertensive patients. Am J Hypertens 14, 908-913.

112. Howard BV, Robbins DC, Sievers ML, et al. (2000) LDL cholesterol as a strong predictor of coronary heart disease in diabetic individuals with insulin resistance and low LDL: the Strong Heart Study. Arterioscler Thromb Vasc Biol 20, 830-835.

113. Guerin M, Le Goff W, Lassel TS, Van Tol A, Steiner G \& Chapman MJ (2001) Atherogenic role of elevated CE transfer from HDL to VLDL(1) and dense LDL in type 2 diabetes: impact of the degree of triglyceridemia. Arterioscler Thromb Vasc Biol 21, 282-288.

114. Schaefer EJ, McNamara JR, Shah PK, Nakajima K, Cupples LA, Ordovas JM \& Wilson PW (2002) Elevated remnantlike particle cholesterol and triglyceride levels in diabetic men and women in the Framingham Offspring Study. Diabetes Care 25, 989-994.

115. Masding MG, Stears AJ, Burdge GC, Wootton SA \& Sandeman DD (2003) Premenopausal advantages in postprandial lipid metabolism are lost in women with type 2 diabetes. Diabetes Care 26, 3243-3249.

116. Masding MG, Stears AJ, Burdge GC, Wootton SA \& Sandeman DD (2006) The benefits of oestrogens on postprandial lipid metabolism are lost in post-menopausal women with type 2 diabetes. Diabet Med 23, 768-774.

117. Fielding CJ, Shore VG \& Fielding PE (1972) A protein cofactor of lecithin:cholesterol acyltransferase. Biochem Biophys Res Commun 46, 1493-1498.

118. Reichl D \& Miller NE (1989) Pathophysiology of reverse cholesterol transport. Insights from inherited disorders of lipoprotein metabolism. Arteriosclerosis 9, 785-797.

119. Calabresi L, Cassinotti M, Gianfranceschi G, Safa O, Murakami T, Sirtori CR \& Franceschini G (1993) Increased postprandial lipemia in Apo A-IMilano carriers. Arterioscler Thromb 13, 521-528.

120. Marin C, Lopez-Miranda J, Gomez P, Paz E, Perez-Martinez P, Fuentes F, Jimenez-Pereperez JA, Ordovas JM \& PerezJimenez F (2002) Effects of the human apolipoprotein A-I promoter G-A mutation on postprandial lipoprotein metabolism. Am J Clin Nutr 76, 319-325.

121. Ordovas JM, Cassidy DK, Civeira F, Bisgaier CL \& Schaefer EJ (1989) Familial apolipoprotein A-I, C-III, and A-IV deficiency and premature atherosclerosis due to deletion of a gene complex on chromosome 11. J Biol Chem 264, 16339-16342.

122. Goldberg IJ, Scheraldi CA, Yacoub LK, Saxena U \& Bisgaier CL (1990) Lipoprotein apoC-II activation of lipoprotein lipase. Modulation by apolipoprotein A-IV. J Biol Chem 265, 4266-4272.

123. Steinmetz A \& Utermann G (1985) Activation of lecithin: cholesterol acyltransferase by human apolipoprotein A-IV. J Biol Chem 260, 2258-2264.

124. Menzel HJ, Sigurdsson G, Boerwinkle E, Schrangl-Will S, Dieplinger H \& Utermann G (1990) Frequency and effect of human apolipoprotein A-IV polymorphism on lipid and lipoprotein levels in an Icelandic population. Hum Genet 84, 344-346.

125. de Knijff P, Johansen LG, Rosseneu M, Frants RR, Jespersen J \& Havekes LM (1992) Lipoprotein profile of a Greenland Inuit population. Influence of anthropometric variables, apo $\mathrm{E}$ and A4 polymorphism, and lifestyle. Arterioscler Thromb 12, 1371-1379.

126. Ostos MA, Lopez-Miranda J, Marin C, Castro P, Gomez P, Paz E, Jimenez Pereperez JA, Ordovas JM \& Perez-Jimenez F (2000) The apolipoprotein A-IV-360His polymorphism determines the dietary fat clearance in normal subjects. Atherosclerosis 153, 209-217.

127. Ostos MA, Lopez-Miranda J, Ordovas JM, Marin C, Blanco A, Castro P, Lopez-Segura F, Jimenez-Pereperez J \& Perez-Jimenez F (1998) Dietary fat clearance is modulated by genetic variation in apolipoprotein A-IV gene locus. J Lipid Res 39, 2493-2500.

128. Weinberg RB, Cook VR, Beckstead JA, Martin DD, Gallagher JW, Shelness GS \& Ryan RO (2003) Structure and interfacial properties of human apolipoprotein A-V. J Biol Chem 278, 34438-34444.

129. Ribalta J, Figuera L, Fernandez-Ballart J, Vilella E, Castro Cabezas M, Masana L \& Joven J (2002) Newly identified apolipoprotein AV gene predisposes to high plasma triglycerides in familial combined hyperlipidemia. Clin Chem 48, $1597-1600$.

130. Vrablik M, Horinek A, Ceska R, Adamkova V, Poledne R \& Hubacek JA (2003) Ser19 $\rightarrow$ Trp polymorphism within the apolipoprotein AV gene in hypertriglyceridaemic people. J Med Genet 40, e105.

131. Masana L, Ribalta J, Salazar J, Fernandez-Ballart J, Joven J \& Cabezas MC (2003) The apolipoprotein AV gene and diurnal triglyceridaemia in normolipidaemic subjects. Clin Chem Lab Med 41, 517-521.

132. Jang Y, Kim JY, Kim OY, Lee JE, Cho H, Ordovas JM \& Lee $\mathrm{JH}(2004)$ The $-1131 \mathrm{~T} \rightarrow \mathrm{C}$ polymorphism in the apolipoprotein A5 gene is associated with postprandial hypertriacylglycerolemia; elevated small, dense LDL concentrations, and oxidative stress in nonobese Korean men. Am J Clin Nutr 80, 832-840.

133. Moreno R, Perez-Jimenez F, Marin C, et al. (2006) A single nucleotide polymorphism of the apolipoprotein $\mathrm{A}-\mathrm{V}$ gene $-1131 \mathrm{~T}>\mathrm{C}$ modulates postprandial lipoprotein metabolism. Atherosclerosis 189, 163-168.

134. Carlsson P, Darnfors C, Olofsson SO \& Bjursell G (1986) Analysis of the human apolipoprotein $\mathrm{B}$ gene; complete structure of the B-74 region. Gene 49, 29-51.

135. Lopez-Miranda J, Ordovas JM, Ostos MA, et al. (1997) Dietary fat clearance in normal subjects is modulated by genetic variation at the apolipoprotein B gene locus. Arterioscler Thromb Vasc Biol 17, 1765-1773.

136. Boerwinkle E \& Chan L (1989) A three codon insertion/deletion polymorphism in the signal peptide region of the human apolipoprotein B (APOB) gene directly typed by the polymerase chain reaction. Nucleic Acids Res 17, 4003. 
137. Byrne CD, Wareham NJ, Mistry PK, Phillips DI, Martensz ND, Halsall D, Talmud PJ, Humphries SE \& Hales CN (1996) The association between free fatty acid concentrations and triglyceride-rich lipoproteins in the post-prandial state is altered by a common deletion polymorphism of the apo B signal peptide. Atherosclerosis 127, 35-42.

138. Regis-Bailly A, Fournier B, Steinmetz J, Gueguen R, Siest G \& Visvikis S (1995) Apo B signal peptide insertion/deletion polymorphism is involved in postprandial lipoparticles' responses. Atherosclerosis 118, 23-34.

139. Weisgraber KH, Mahley RW, Kowal RC, Herz J, Goldstein JL \& Brown MS (1990) Apolipoprotein C-I modulates the interaction of apolipoprotein $\mathrm{E}$ with beta-migrating very low density lipoproteins (beta-VLDL) and inhibits binding of beta-VLDL to low density lipoprotein receptor-related protein. J Biol Chem 265, 22453-22459.

140. Sehayek E \& Eisenberg S (1991) Mechanisms of inhibition by apolipoprotein $\mathrm{C}$ of apolipoprotein E-dependent cellular metabolism of human triglyceride-rich lipoproteins through the low density lipoprotein receptor pathway. J Biol Chem 266, 18259-18267.

141. Jong MC, Hofker MH \& Havekes LM (1999) Role of apoCs in lipoprotein metabolism: functional differences between apoC1, apoC2, and apoC3. Arterioscler Thromb Vasc Biol 19, $472-484$.

142. Waterworth DM, Hubacek JA, Pitha J, Kovar J, Poledne R, Humphries SE \& Talmud PJ (2000) Plasma levels of remnant particles are determined in part by variation in the APOC3 gene insulin response element and the APOCI-APOE cluster. J Lipid Res 41, 1103-1109.

143. Woo SK \& Kang HS (2003) The apolipoprotein CIII T2854G variants are associated with postprandial triacylglycerol concentrations in normolipidemic Korean men. J Hum Genet 48, 551-555.

144. Beisiegel U, Weber W, Ihrke G, Herz J \& Stanley KK (1989) The LDL-receptor-related protein, LRP, is an apolipoprotein E-binding protein. Nature 341, 162-164.

145. Gylling H, Hallikainen M, Pihlajamaki J, Agren J, Laakso M, Rajaratnam RA, Rauramaa R \& Miettinen TA (2004) Polymorphisms in the ABCG5 and ABCG8 genes associate with cholesterol absorption and insulin sensitivity. J Lipid Res $\mathbf{4 5}$, $1660-1665$.

146. Mahley RW (1988) Apolipoprotein E:cholesterol transport protein with expanding role in cell biology. Science 240, 622-630.

147. Mahley RW, Palaoglu KE, Atak Z, et al. (1995) Turkish Heart Study: lipids, lipoproteins, and apolipoproteins. J Lipid Res 36, 839-859.

148. Weintraub MS, Eisenberg S \& Breslow JL (1987) Dietary fat clearance in normal subjects is regulated by genetic variation in apolipoprotein E. J Clin Invest 80, 1571-1577.

149. Dart A, Sherrard B \& Simpson H (1997) Influence of apo E phenotype on postprandial triglyceride and glucose responses in subjects with and without coronary heart disease. Atherosclerosis 130, 161-170.

150. Dallongeville J, Tiret L, Visvikis S, et al. (1999) Effect of apo E phenotype on plasma postprandial triglyceride levels in young male adults with and without a familial history of myocardial infarction: the EARS II study. European Atherosclerosis Research Study. Atherosclerosis 145, 381-388.

151. Cardona F, Morcillo S, Gonzalo-Marin M \& Tinahones FJ (2005) The apolipoprotein E genotype predicts postprandial hypertriglyceridemia in patients with the metabolic syndrome. J Clin Endocrinol Metab 90, 2972-2975.

152. Mui S, Briggs M, Chung H, Wallace RB, Gomez-Isla T, Rebeck GW \& Hyman BT (1996) A newly identified polymorphism in the apolipoprotein $\mathrm{E}$ enhancer gene region is associated with Alzheimer's disease and strongly with the epsilon 4 allele. Neurology 47, 196-201.

153. Artiga MJ, Bullido MJ, Sastre I, Recuero M, Garcia MA, Aldudo J, Vazquez J \& Valdivieso F (1998) Allelic polymorphisms in the transcriptional regulatory region of apolipoprotein E gene. FEBS Lett 421, 105-108.

154. Boisfer E, Lambert G, Atger V, et al. (1999) Overexpression of human apolipoprotein A-II in mice induces hypertriglyceridemia due to defective very low density lipoprotein hydrolysis. J Biol Chem 274, 11564-11572.

155. Viitanen L, Pihlajamaki J, Miettinen R, Karkkainen P, Vauhkonen I, Halonen P, Kareinen A, Lehto S \& Laakso M (2001) Apolipoprotein E gene promoter $(-219 \mathrm{G} / \mathrm{T})$ polymorphism is associated with premature coronary heart disease. J Mol Med 79, 732-737.

156. Moreno JA, Lopez-Miranda J, Marin C, et al. (2003) The influence of the apolipoprotein E gene promoter $(-219 \mathrm{G} / \mathrm{T})$ polymorphism on postprandial lipoprotein metabolism in young normolipemic males. J Lipid Res 44, 2059-2064.

157. Matarese V, Stone RL, Waggoner DW \& Bernlohr DA (1989) Intracellular fatty acid trafficking and the role of cytosolic lipid binding proteins. Prog Lipid Res 28, 245-272.

158. Baier LJ, Sacchettini JC, Knowler WC, et al. (1995) An amino acid substitution in the human intestinal fatty acid binding protein is associated with increased fatty acid binding, increased fat oxidation, and insulin resistance. $J$ Clin Invest 95, 1281-1287.

159. Hegele RA, Harris SB, Hanley AJ, Sadikian S, Connelly PW \& Zinman B (1996) Genetic variation of intestinal fatty acidbinding protein associated with variation in body mass in aboriginal Canadians. $J$ Clin Endocrinol Metab 81, 4334-4337.

160. Yamada K, Yuan X, Ishiyama S, Koyama K, Ichikawa F, Koyanagi A, Koyama W \& Nonaka K (1997) Association between Ala54Thr substitution of the fatty acid-binding protein 2 gene with insulin resistance and intra-abdominal fat thickness in Japanese men. Diabetologia 40, 706-710.

161. Agren JJ, Valve R, Vidgren H, Laakso M \& Uusitupa M (1998) Postprandial lipemic response is modified by the polymorphism at codon 54 of the fatty acid-binding protein 2 gene. Arterioscler Thromb Vasc Biol 18, 1606-1610.

162. Georgopoulos A, Aras O \& Tsai MY (2000) Codon-54 polymorphism of the fatty acid-binding protein 2 gene is associated with elevation of fasting and postprandial triglyceride in type 2 diabetes. J Clin Endocrinol Metab 85, 3155-3160.

163. Tahvanainen E, Molin M, Vainio S, Tiret L, Nicaud V, Farinaro E, Masana L \& Ehnholm C (2000) Intestinal fatty acid binding protein polymorphism at codon 54 is not associated with postprandial responses to fat and glucose tolerance tests in healthy young Europeans. Results from EARS II participants. Atherosclerosis 152, 317-325.

164. Dworatzek PD, Hegele RA \& Wolever TM (2004) Postprandial lipemia in subjects with the threonine 54 variant of the fatty acid-binding protein 2 gene is dependent on the type of fat ingested. Am J Clin Nutr 79, 1110-1117.

165. Gertow K, Skoglund-Andersson C, Eriksson P, Boquist S, Orth-Gomer K, Schenck-Gustafsson K, Hamsten A \& Fisher RM (2003) A common polymorphism in the fatty acid transport protein-1 gene associated with elevated post-prandial lipaemia and alterations in LDL particle size distribution. Atherosclerosis 167, 265-273.

166. Beisiegel U, Weber W \& Bengtsson-Olivecrona G (1991) Lipoprotein lipase enhances the binding of chylomicrons to low density lipoprotein receptor-related protein. Proc Natl Acad Sci U S A 88, 8342-8346.

167. Talmud PJ, Hall S, Holleran S, Ramakrishnan R, Ginsberg HN \& Humphries SE (1998) LPL promoter - 93T/G transition 
influences fasting and postprandial plasma triglycerides response in African-Americans and Hispanics. J Lipid Res 39, 1189-1196.

168. Fisher RM, Humphries SE \& Talmud PJ (1997) Common variation in the lipoprotein lipase gene: effects on plasma lipids and risk of atherosclerosis. Atherosclerosis 135, 145-159.

169. Gerdes C, Fisher RM, Nicaud V, Boer J, Humphries SE, Talmud PJ \& Faergeman O (1997) Lipoprotein lipase variants D9N and N291S are associated with increased plasma triglyceride and lower high-density lipoprotein cholesterol concentrations: studies in the fasting and postprandial states: the European Atherosclerosis Research Studies. Circulation 96, 733-740.

170. Mero N, Suurinkeroinen L, Syvanne M, Knudsen P, Yki-Jarvinen H \& Taskinen MR (1999) Delayed clearance of postprandial large TAG-rich particles in normolipidemic carriers of LPL Asn291Ser gene variant. J Lipid Res 40, $1663-1670$.

171. Lopez-Miranda J, Cruz G, Gomez P, Marin C, Paz E, PerezMartinez P, Fuentes FJ, Ordovas JM \& Perez-Jimenez F (2004) The influence of lipoprotein lipase gene variation on postprandial lipoprotein metabolism. $J$ Clin Endocrinol Metab 89, 4721-4728.

172. van't Hooft FM, Lundahl B, Ragogna F, Karpe F, Olivecrona G \& Hamsten A (2000) Functional characterization of 4 polymorphisms in promoter region of hepatic lipase gene. Arterioscler Thromb Vasc Biol 20, 1335-1339.

173. Jansen H, Chu G, Ehnholm C, Dallongeville J, Nicaud V \& Talmud PJ (1999) The T allele of the hepatic lipase promoter variant $\mathrm{C}-480 \mathrm{~T}$ is associated with increased fasting lipids and HDL and increased preprandial and postprandial LpCIII:B: European Atherosclerosis Research Study (EARS) II. Arterioscler Thromb Vasc Biol 19, 303-308.
174. Gomez P, Miranda JL, Marin C, Bellido C, Moreno JA, Moreno R, Perez-Martinez P \& Perez-Jimenez F (2004) Influence of the $-514 \mathrm{C} / \mathrm{T}$ polymorphism in the promoter of the hepatic lipase gene on postprandial lipoprotein metabolism. Atherosclerosis 174, 73-79.

175. Karpe F, Lundahl B, Ehrenborg E, Eriksson P \& Hamsten A (1998) A common functional polymorphism in the promoter region of the microsomal triglyceride transfer protein gene influences plasma LDL levels. Arterioscler Thromb Vasc Biol 18, 756-761.

176. Lundahl B, Hamsten A \& Karpe F (2002) Postprandial plasma ApoB-48 levels are influenced by a polymorphism in the promoter of the microsomal triglyceride transfer protein gene. Arterioscler Thromb Vasc Biol 22, 289-293.

177. Hauser H, Dyer JH, Nandy A, et al. (1998) Identification of a receptor mediating absorption of dietary cholesterol in the intestine. Biochemistry 37, 17843-17850.

178. Bietrix F, Yan D, Nauze M, et al. (2006) Accelerated lipid absorption in mice overexpressing intestinal SR-BI. J Biol Chem 281, 7214-7219.

179. Perez-Martinez P, Lopez-Miranda J, Ordovas JM, et al. (2004) Postprandial lipemia is modified by the presence of the polymorphism present in the exon 1 variant at the SR-BI gene locus. J Mol Endocrinol 32, 237-245.

180. Corella D, Qi L, Tai ES, Deurenberg-Yap M, Tan CE, Chew SK \& Ordovas JM (2006) Perilipin gene variation determines higher susceptibility to insulin resistance in Asian women when consuming a high-saturated fat, low-carbohydrate diet. Diabetes Care 29, 1313-1319.

181. Phillips C, Mullan K, Owens D \& Tomkin GH (2004) Microsomal triglyceride transfer protein polymorphisms and lipoprotein levels in type 2 diabetes. QJM 97, 211-218. 